\title{
Identification and Optimization of cell active 4-anilino- quin(az)oline Inhibitors for Protein Kinase Novel 3 (PKN3)
}

\author{
Christopher R. M. Asquith ${ }^{[a, b] * \wedge}$, Louisa Temme ${ }^{[b] \wedge}$, Tuomo Laitinen ${ }^{[c]}$, Julie Pickett ${ }^{[b]}$, Frank E. \\ Kwarcinski ${ }^{[d]}$, Parvathi Sinha ${ }^{[d]}$, Carrow I. Wells ${ }^{[b]}$, Graham J. Tizzard ${ }^{[e]}$, Reena Zutshil ${ }^{[d]}$, David H. \\ Drewry ${ }^{[b] *}$
}

\begin{abstract}
The development of a small library of 4anilinoquinolines led to the identification of 7 -iodo- $N$ - $(3,4,5$ trimethoxyphenyl)quinolin-4-amine $\mathbf{1 6}$ as a potent inhibitor of Protein Kinase Novel 3 (PKN3) with an $\mathrm{IC}_{50}$ of $1.3 \mu \mathrm{M}$ in cells. Compound 16 presents a useful potential tool compound to study the biology of PKN3 including links to pancreatic and prostate cancer, along with T-cell acute lymphoblastic leukemia. These compounds may be useful tools to explore the therapeutic potential of PKN3 inhibition in prevention of a broad range of infectious and systemic diseases.
\end{abstract}

Protein kinase $\mathrm{N}$ (PKN, protein kinase novel) family genes encode for the three isoforms PKN1 (PKNa/PRK1/PAK1), PKN2 (PKNy/PRK2/PAK2/) and PKN3 (PKN 3$)$ that form the subfamily of AGC serine/threonine protein kinases. ${ }^{[1]} \mathrm{PKNs}$ are closely related to novel isoforms of the protein kinase $C$ family and are therefore also named PRKs (protein kinase C-related kinases). ${ }^{[2,3]}$ More in detail, the catalytic domain of the mammalian PKN is homologous to protein kinase $\mathrm{C}$ family members at its $\mathrm{C}$-terminal region and contains three repeats of an antiparallel coiled-coil (ACC) domain and a C2-like domain at its $N$-terminal region. ${ }^{[4,1]}$ All these domains are well-conserved among the PKN isoforms but the enzymatic properties and tissue distributions of PKN1-3 differ. ${ }^{[1]}$ While PKN1 and PKN2 are expressed ubiquitously PKN3 is only found in restricted tissues including skeletal muscle, heart, liver and human cancer cell lines. ${ }^{[2,4-6]}$

Full catalytic activation of $\mathrm{PKN} 1-3$ requires phosphorylation of the activation loop by phosphoinositide-dependent kinase 1 (PDK1) and turn motif phosphorylation. ${ }^{[2,4]}$ PKN 1-3 differ in their responsiveness regarding activation by members of the small GTPase Rho, phospholipids, fatty acids and arachidonic acid. ${ }^{[3,4}$ 7] Mukai et al. investigated the physiological role of PKN3 in normal tissue with the help of PKN3 KO mice. ${ }^{[7]}$ It was shown that PKN3 is not required for development and growth to the adult stage, but lower migratory activity of embryonic fibroblast cells was observed suggesting PKN3 involvement in the actin cytoskeleton regulation of primary fibroblastic cells. ${ }^{[7]}$ Additionally, normal vascular development does not require PKN3 but plays a role in angiogenesis support. Tumor angiogenesis is not inhibited by PKN3 KO. ${ }^{[1]}$

\section{[a] Dr. C. R. M. Asquith}

Department of Pharmacology, School of Medicine, University of North Carolina at Chapel Hill, NC 27599, (USA)

E-mail: chris.asquith@unc.edu

[b] Dr. C. R. M. Asquith, Dr. L. Temme, C. I. Wells, Dr. D. H. Drewry Structural Genomics Consortium, UNC Eshelman School of Pharmacy, University of North Carolina at Chapel Hill, Chapel Hill, NC 27599, (USA)

E-mail: david.drewry@unc.edu

[c] Dr. T. Laitinen

School of Pharmacy, Faculty of Health Sciences, University of Eastern Finland, 70211 Kuopio, (Finland)

[d] Dr. Frank E. Kwarcinski, Parvathi Sinha, Dr. Reena Zutshi Luceome Biotechnologies, LLC, Tucson, AZ 85719 (USA)

[e] Dr. Graham J. Tizzard

School of Chemistry, University of Southampton, Southampton, SO17 1BJ, (United Kingdom)
However, PKN3 is involved in other pathological processes. Thus, PKN3 has shown to interact with a mediator of tumor invasion and metastasis in epithelial cancers, $\mathrm{RhoC},{ }^{[8]}$ and with p130Cas, known to regulate cancer cell growth and invasiveness. ${ }^{[9]}$ PKN3 acts downstream of phosphoinositide 3kinase (PI3K). Growth factor stimulation of normal cells leads to transiently activated $\mathrm{PI} 3 \mathrm{~K}$, which is rapidly turned off by the phosphatase and tensin homolog (PTEN). ${ }^{[5]}$ However, most frequently PTEN is inactivated in human cancer resulting in overactivation of the PI3K pathway, which in turn upregulates PKN3 and increases metastatic behavior. ${ }^{\left[{ }^{[9]}\right.}$ This is one of the processes that mediate malignant cell growth in prostate cancer. ${ }^{[5]}$ Additionally, the malignant behavior of breast cancer cells in vitro increased by overexpression of exogenous PKN3. ${ }^{[8]}$ Since PKN3 can act downstream of PI3K signaling, ${ }^{[5,8]}$ therapeutics that selectively inhibit PKN3 could provide valuable insights in the role of PKN3 in cancer biology and represent a promising approach to target these cancer types that lack tumor suppressor PTEN function or rely on chronic activation of PI3K. [5] Thus, PKN3 inhibition was observed to result in growth inhibition of prostate and breast cancer xenografts that were PI3K-driven. ${ }^{[5}$, 8, 10]

An siRNA formulation (Atu027) that knocks down PKN3 in vivo, preventing liver and lung metastases in mouse models and inhibiting prostate and pancreatic cancer growth passed phase I clinical trial and has advanced to the ongoing phase $\mathrm{I} / \mathrm{II}$ trial in advanced pancreatic cancer (NCT01808638). ${ }^{[11,12]}$ Atu027 was well tolerated, no responses of the innate immune system, often a problem with siRNA formulations, were observed and the treatment was not restricted to a type of cancer. It was anticipated that beneficial effects could be seen in all vascularized metastatic cancers. ${ }^{[12]}$ However, dose limiting toxicity was not reached in the phase I clinical trial and the potential remaining drawbacks of this siRNA approach include enzymatic instability, off-target effects, challenges in tissue-specific access due to their negative charge and size as well as rapid liver clearance and renal excretion. ${ }^{[12-15]}$

Additionally this PI3K pathway was found to be overactivated in many types of leukemia, ${ }^{[10,16-18]}$ the expression level of PKN3 was significantly increased in human T-cell acute lymphoblastic leukaemia (T-ALL) and PKN3 deletion slowed TALL development without affecting normal hematopoiesis. ${ }^{[10]}$ PKN3 was also found to be a possible regulator of neovascularization and its inhibition might be beneficial for vascular diseases like arthritis and age-related macular degeneration. ${ }^{[7]}$ Another possible therapeutic field covers bone diseases like rheumatoid arthritis and osteoporosis since, downstream of the Wnt5a-Ror2-Rho signaling pathway, PKN3 facilitates bone resorption. ${ }^{[19]}$ The development of a PKN3 chemical probe would significantly enhance the understanding around the role of PKN3.[20] Despite some reported PKN3 inhibitors (Figure 1), ${ }^{[7,21]}$ wider structure activity relationships and kinome selectivity are yet to be explored. ${ }^{[21-25]}$

In order to develop a tractable lead compound for PKN3, we first looked at PKN3 inhibition using the well characterized second generation GlaxoSmithKline Published Kinase Inhibitor 
bioRxiv preprint doi: https://doi.org/10.1101/2020.03.02.972943; this version posted March 3, 2020. The copyright holder for this preprint (which was not certified by peer review) is the author/funder, who has granted bioRxiv a license to display the preprint in perpetuity. It is made available under aCC-BY-NC 4.0 International license.

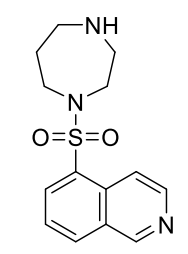

Fasudil (HA-1077) $\left(K_{\mathrm{i}}: 110 \mathrm{nM}\right)$

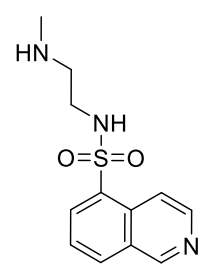

$\mathrm{H}-8$

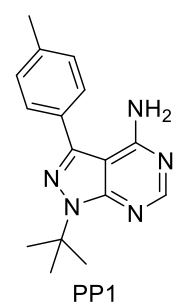

$\left(K_{\mathrm{i}}: 1.3 \mathrm{nM}\right)$<smiles>Oc1ccc(-c2nc(-c3ccc(F)cc3)c(-c3ccncc3)[nH]2)cc1</smiles>

SB-202190

$\left(K_{\mathrm{i}}: 4 \mathrm{nM}\right)$
$\left(K_{\mathrm{i}}: 10 \mathrm{nM}\right)$

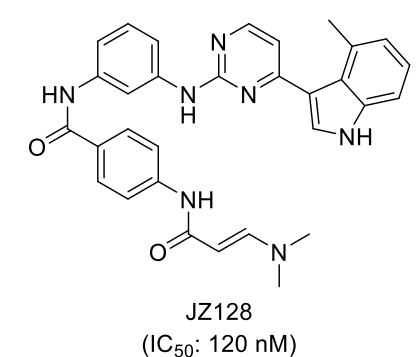

Figure 1. Previously reported compounds active against PKN3.

Sets (PKIS2). ${ }^{[24-25]}$ PKN3 was not part of the DiscoverX KinomeSCAN ${ }^{\circledR}$ screen and is a historically understudied kinase, so we first screened PKIS2 against PKN3 in a split-luciferase binding assay ${ }^{[29-30]}$ and identified a set of 4-anilinoquinolines (1-3) with a common trimethoxyaniline motif (Figure 2). Compound 2 only hit four other kinases (GAK, RIPK2, ADCK3 and NLK) under $1 \mu \mathrm{M}$ with PKN3 the third most potent $\left(K_{\mathrm{i}}=280 \mathrm{nM}\right)$. Compound 3 highlighted there was an ability to increase potency on PKN3 the signal digit nanomolar on PKN3. The kinome promiscuity profile of 3 (>18 kinases at $1 \mu \mathrm{M}$ ) was undesirable when looking for a narrow spectrum kinase inhibitor.

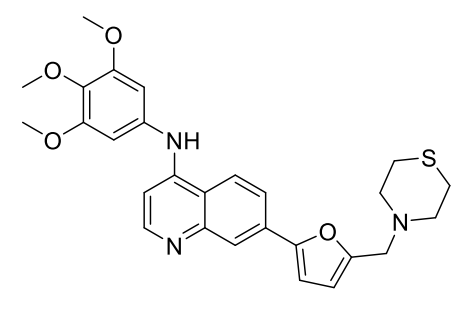

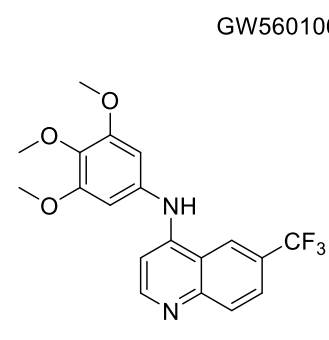

GW577382 (2) $\left(\mathrm{IC}_{50}: 280 \mathrm{nM}\right)$<smiles>COc1cc(Nc2ccnc3cc(-c4ccncc4)ccc23)cc(OC)c1OC</smiles>

GW494610 (3)

$\left(\mathrm{IC}_{50}: 9 \mathrm{nM}\right)$
Figure 2. 4-Anilinoquinolines identified as $P K N 3$ inhibitors from PKIS2.

A small series of 4 -anilinoquin(az)oline literature inhibitors was also screened in the PKN3 binding assay (Table 1). While cabozantinib and sapitinib were weak inhibitors of PKN3, gefitinib and lapatinib showed moderate activity. Vandetanib and tesevatinib revealed both $\mathrm{IC}_{50}$ values below $1 \mu \mathrm{M}$ which further highlights the potential of this scaffold and the need for further structural modification to 2 , to improve its potency and selectivity towards PKN3.

To probe the structural requirements and improve potency for PKN3 inhibition we synthesized a series of analogs (Scheme 1). 4-Anilinoquinolines were prepared by heating the corresponding 4-chloroquinoline derivative and substituted aniline in ethanol to reflux overnight. ${ }^{[31-35]}$ The synthesis afforded products $(2,4-57)$ in good to excellent yield (24-93\%).

Table 1. Literature 4-anilinoquin(az)oline PKN3 results.

\begin{tabular}{c|c}
\hline Compound & PKN3 IC $_{50}(\mu \mathrm{M})^{\mathrm{a}}$ \\
\hline Cabozantinib & 42 \\
Sapitinib (AZD8931) & 44 \\
Gefitinib & 23 \\
Lapatinib & 5.9 \\
Vandetanib & 0.54 \\
Tesevatinib (XL-647) & 0.24 \\
\hline${ }^{\text {II }}$ 50 $_{50}$ values generated in SLCA assay $(\mathrm{n}=2)^{[29-30]}$
\end{tabular}

We first synthesized direct analogs of $\mathbf{2}$ with a two pronged strategy to improve potency on PKN3 and to overcome the innate GAK activity of this scaffold through divergent SAR. ${ }^{[31-35]}$ Analogs for GW577382 were previously used to generate a selective chemical probe for GAK. ${ }^{[31-33]}$ Hence, literature GAK nanoBRET data were used as a guide to GAK activity of the compounds as the GAK activity is the eventual probe quality benchmark for potency and selectivity. The compounds were initially screened for PKN3 binding in the split-luciferase binding assay (SLCA assay), ${ }^{[29-30]}$ in a 8-point dose response format to determine the $\mathrm{IC}_{50}$ values (Table 2 ).<smiles>Clc1[Y]cnc2ccccc12</smiles>

$\mathrm{X}=\mathrm{CH}$ and $\mathrm{N}$

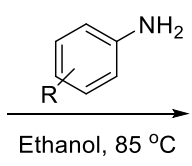

Ethanol, $85^{\circ} \mathrm{C}$

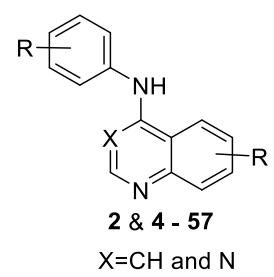

Scheme 1. General synthetic route to analogs (2 \& 4 - 57).

The synthesized 6-trifluoromethyl quinoline 2 was active on PKN3 $\left(\mathrm{IC}_{50}=280 \mathrm{nM}\right)$ and had potent GAK activity in cells $\left(\mathrm{IC}_{50}=290 \mathrm{nM}\right)$. A switch to quinazoline (4) resulted in a decrease of activity by 15 -fold on PKN3, but 25 -fold on GAK. Removal of the 6-trifluoromethyl moiety from the quinoline scaffold (5) also led to a 3-4-fold drop on both PKN3 and GAK compared to 2.

However, addition of a fluoro group in 6-position (6) increased potency on GAK by 3-fold, with nearly no change on PKN3. The corresponding quinazoline 7 showed a similar decrease in activity on both kinases as with compound 4 . The addition of a chloro atom in 6-position (8) resulted in a 4 -fold increased activity on PKN3 $\left(\mathrm{IC}_{50}=70 \mathrm{nM}\right)$ and a maintenance of GAK activity $\left(\mathrm{IC}_{50}=210 \mathrm{nM}\right)$. Increasing the size of the substituent to the bromo (9) realized a compound with single digit nanomolar activity $\left(\mathrm{IC}_{50}=9.3 \mathrm{nM}\right)$ and a 5 -fold window over GAK in cells $\left(\mathrm{IC}_{50}\right.$ $=48 \mathrm{nM}$ ) as well as a known narrow spectrum on the kinome. ${ }^{[31-}$ ${ }^{33} \mathrm{~A}$ further increase of the halogen atom size to the iodo (10) led to a decrease in activity compared to $\mathbf{9}$ in line with activities observed in the chloro-substituted compound $\mathbf{8}$. The corresponding quinazoline $\mathbf{1 1}$ showed a drop off in PKN3 activity (27-fold) but a shallower drop off in GAK activity (8-fold).

The 7-fluoro isomer 12 showed a 2-fold lower potency than the corresponding 6 -fluoro analog 6 on GAK. The quinazoline analog 13 revealed a sustainable lower $I_{50}$ value which is consistent with the potency of previous analogs 4,7 and 11. The increase of the atom size to a chloro atom in this 6-position of 14 resulted in the first compound that showed an increased selectivity between PKN3 and GAK with a 10-fold difference in activities $\left(\mathrm{IC}_{50}=27 \mathrm{nM}\right.$ vs $250 \mathrm{nM}$ ). Surprisingly, the bromo derivative 15 reduced the selectivity to 2-fold, driven by a 4-fold decrease in PKN3 and a maintaining of GAK activity. The iodo analog 16 was potent on 
bioRxiv preprint doi: https://doi.org/10.1101/2020.03.02.972943; this version posted March 3, 2020. The copyright holder for this preprint (which was not certified by peer review) is the author/funder, who has granted bioRxiv a license to display the preprint in perpetuity. It is made available under aCC-BY-NC 4.0 International license.

Table 2. Results of initial optimization of 2.

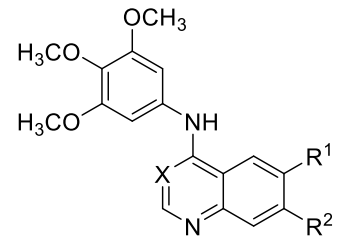

\begin{tabular}{|c|c|c|c|c|c|}
\hline \multirow[b]{2}{*}{ Cmpd } & \multirow[b]{2}{*}{$x$} & \multirow[b]{2}{*}{$\mathbf{R}^{1}$} & \multirow[b]{2}{*}{$\mathbf{R}^{2}$} & PKN3 $^{a}$ & $\mathbf{G A K}^{\mathrm{b}}$ \\
\hline & & & & $\begin{array}{l}\mathrm{IC}_{50} \\
(\mu \mathrm{M})\end{array}$ & $\begin{array}{c}\text { in-cell IC } \mathbf{C}_{50} \\
(\mu \mathrm{M})\end{array}$ \\
\hline 2 & $\mathrm{H}$ & $\mathrm{CF}_{3}$ & $\mathrm{H}$ & 0.28 & 0.18 \\
\hline 4 & $\mathrm{~N}$ & $\mathrm{CF}_{3}$ & $\mathrm{H}$ & 4.4 & 4.5 \\
\hline 5 & $\mathrm{H}$ & $\mathrm{H}$ & $\mathrm{H}$ & 1.1 & 0.78 \\
\hline 6 & $\mathrm{H}$ & $\mathrm{F}$ & $\mathrm{H}$ & 0.70 & 0.27 \\
\hline 7 & $\mathrm{~N}$ & $\mathrm{~F}$ & $\mathrm{H}$ & 5.8 & 3.6 \\
\hline 8 & $\mathrm{H}$ & $\mathrm{Cl}$ & $\mathrm{H}$ & 0.070 & 0.21 \\
\hline 9 & $\mathrm{H}$ & $\mathrm{Br}$ & $\mathrm{H}$ & 0.0093 & 0.048 \\
\hline 10 & $\mathrm{H}$ & I & $\mathrm{H}$ & 0.098 & 0.11 \\
\hline 11 & $\mathrm{~N}$ & I & $\mathrm{H}$ & 2.7 & 0.89 \\
\hline 12 & $\mathrm{H}$ & $\mathrm{H}$ & $\mathrm{F}$ & 0.39 & 0.51 \\
\hline 13 & $\mathrm{~N}$ & $\mathrm{H}$ & $\mathrm{F}$ & 3.9 & $>5$ \\
\hline 14 & $\mathrm{H}$ & $\mathrm{H}$ & $\mathrm{Cl}$ & 0.027 & 0.25 \\
\hline 15 & $\mathrm{H}$ & $\mathrm{H}$ & $\mathrm{Br}$ & 0.12 & 0.27 \\
\hline 16 & $\mathrm{H}$ & $\mathrm{H}$ & 1 & 0.014 & 0.074 \\
\hline 17 & $\mathrm{~N}$ & $\mathrm{H}$ & 1 & 0.93 & 2.4 \\
\hline 18 & $\mathrm{H}$ & ${ }^{t} \mathrm{Bu}$ & $\mathrm{H}$ & 0.31 & 0.33 \\
\hline 19 & $\mathrm{H}$ & $\mathrm{CN}$ & $\mathrm{H}$ & 0.21 & 0.35 \\
\hline 20 & $\mathrm{H}$ & $\mathrm{SO}_{2} \mathrm{CH}_{3}$ & $\mathrm{H}$ & 0.60 & 3.1 \\
\hline 21 & $\mathrm{H}$ & $\mathrm{OCH}_{3}$ & $\mathrm{H}$ & 0.74 & 0.28 \\
\hline 22 & $\mathrm{H}$ & $\mathrm{OCH}_{3}$ & $\mathrm{OCH}_{3}$ & 0.48 & 0.025 \\
\hline 23 & $\mathrm{H}$ & $\mathrm{H}$ & $\mathrm{OCH}_{3}$ & 0.92 & 0.44 \\
\hline 24 & $\mathrm{H}$ & $\mathrm{H}$ & $\mathrm{CF}_{3}$ & 0.24 & 0.52 \\
\hline 25 & $\mathrm{~N}$ & $\mathrm{H}$ & $\mathrm{CF}_{3}$ & 2.6 & $>5$ \\
\hline 26 & $\mathrm{H}$ & $\mathrm{H}$ & $\mathrm{CN}$ & 0.079 & 0.34 \\
\hline
\end{tabular}

${ }^{a} C_{50}$ values generated in SLCA assay $(n=2)^{[26] ;}$; in-cell $I C_{50}$ values obtained in NanoBRET assay and previously reported ${ }^{[31-33,35]}$

PKN3 $\left(\mathrm{IC}_{50}=14 \mathrm{nM}\right)$ but only 5-fold selective over GAK in cells. The quinazoline analog 17 showed a corresponding drop off in activity, but still showed PKN3 activity under $1 \mu \mathrm{M}$.

The 6-position tert-butyl isomer 18 revealed equipotent activity compared to $\mathbf{2}$ with no overall improvement. This was the same in case of the cyano analog 19. However, 6-methyl sulfonesubstituted compound $\mathbf{2 0}$ showed 5 -fold selectivity towards GAK and moderate potency against PKN3 ( $\left(\mathrm{IC}_{50}: 600 \mathrm{nM}\right)$.

The 6-methoxy (21), 6,7-dimethoxy (22) and 7-methoxy (23) substituted quinolines showed a preference for GAK which is consistent with previously observed SAR showing high potency on GAK. ${ }^{[29]} \mathrm{A}$ switch to the 7-trifluoromethyl moiety (24) was in line with the activities observed for PKN3 and GAK showing a 3-fold reduction in GAK activity compared to 2 . The quinazoline analog 25 showed a consistent sharp drop off in activity for both kinases.
The 7-cyano analog 26 was potent on PKN3 $\left(\mathrm{IC}_{50}=79 \mathrm{nM}\right)$ with 4-fold selectivity over GAK.

In order to find potent analogs that lack GAK activity, we decided to take a look at a small library of lapatinib derivatives following up from the screening of compounds in table 1 and 2. Therefore, a simplified lapatinib scaffold with a 6,7dimethoxyquin(az)oline motif (27-34) was used (Table 3). We know that GAK activity would be removed with addition of substitutions beyond smaller simple groups at the para-position of the aniline.

Switching from lapatinib to the simplified quinoline derivative 27 maintained activity on PKN3 and reduced in-cell EGFR activity by 80 -fold. ${ }^{[33,36]}$ The quinazoline derivative $\mathbf{2 8}$ saw a 2 -fold drop in PKN3 activity and an 80-fold boost in EGFR activity as previously reported. A few changes to the compound to expand the chemical space led to a further reduction in activity (29-31). The acetamide derivative $\mathbf{3 2}$ demonstrated that the benzyl group is important for activity since $\mathbf{3 2}$ showed no binding on either PKN3 or EGFR. ${ }^{[36]}$ Interestingly, the removal of the 7-position methoxy group of $\mathbf{2 9}$ resulting in analog 33 revealing no PKN3 inhibition improvement; however removal of 6-position methoxy in case of $\mathbf{3 4}$ showed a boost of activity of at least 5 -fold $\left(\mathrm{IC}_{50}=11 \mu \mathrm{M}\right)$. Thus, the PKN3 activity is equipotent with in-cell EGFR activity $\left(\mathrm{IC}_{50}=6.3 \mu \mathrm{M}\right) .{ }^{\left[{ }^{[36]}\right.}$

We then considered that the halogen atom in the metaposition may have an effect on the activity profile of the scaffold. In the resulting series GAK is the collateral target of interest. ${ }^{[31-35]}$ A small series of halogenated analogs (35-39) was synthesized to probe this rational (Table 4). Replacing the methoxy groups of 2 and 9 with fluoro atoms resulted in analogs 35 and 36 with occupied meta-positions; both quinolines showed limited activity on both PKN3 and GAK. ${ }^{[35]}$ Removing the substitution of one of the two meta-positions resulted in quinolines $\mathbf{3 7}$ and $\mathbf{3 8}$ with limited activity on both kinases. ${ }^{[35]}$ However, switching back to the trimethoxy substitution and moving the fluoro atom to the 5- and 7-position yielded quinoline $\mathbf{3 9}$ with 8-fold selectivity towards GAK over PKN3 and potency below $1 \mu \mathrm{M} .{ }^{[35]}$

In an attempt to remove the GAK activity from the scaffold while maintaining PKN3 activity the addition of steric bulk in paraposition of the preferred 6-bromo, 6,7-dimethoxy and 5,7-difluoro quinolines was investigated. These compounds (40-57) demonstrated only limited activity on PKN3 in an initial $1 \mu \mathrm{M}(\mathrm{n}=2)$ signal measurement (Table 5). The smaller para-substitutions including ethoxy (40-42), iso-propyl (43-45) and cyclobutyl (4648) were all inactive at $1 \mu \mathrm{M}$. The para-benzyl substituted quinolines 49-51 showed a hint of activity but not in case of 5,7difluoro derivative 51. A further investigation of the 6-bromo and 6,7-dimethoxy quinolines and altering the electronics of the benzyl ring system. This yielded analogs (52-57) with activities similar to lapatinib, but with a higher ligand efficiency due to the removal of the solvent exposed region of lapatinib.

The compounds with the lowest $\mathrm{IC}_{50}$ value in the SLCA assay (8-10 \& 14-16) were screened in a PKN3 NanoBRET assay to test their in-cell target engagement (Table 6). ${ }^{[27-28]}$ The NanoBRET consists of a Nano Luciferase, an extremely bright and small luciferase, fused to the $\mathrm{N}$-terminal of PKN3 and transiently expressed in HEK293 cells. A red-shifted dye tethered to a fragment shown to bind the ATP binding site of PKN3 serves as the cell permeable tracer. This dye added together with the Nano Luciferase enzyme substrate produces a bioluminescence resonance energy transfer (BRET) signal. Addition of smallmolecule PKN3 inhibitors that compete with the tracer of the fusion protein in the ATP-binding site results in a detectable loss of BRET signal. The reduction of this BRET signal is the measurement parameter of the NanoBRET assay and determined at an 8-point dose response to determine an in cell target engagement the cellular binding potency. ${ }^{[37-38]}$

Interestingly, the SLCA and nanoBRET results of this small set of compounds did not have a linear relationship which can partly be explained by cell penetrance among other factors. The most potent compound 9 in the SLCA assay $\left(\mathrm{IC}_{50}=9.3 \mathrm{nM}\right)$ was not the most potent one in the nanoBRET assay $\left(\mathrm{IC}_{50}=3.5 \mu \mathrm{M}\right)$. 
bioRxiv preprint doi: https://doi.org/10.1101/2020.03.02.972943; this version posted March 3, 2020. The copyright holder for this preprint (which was not certified by peer review) is the author/funder, who has granted bioRxiv a license to display the preprint in perpetuity. It is made available under aCC-BY-NC 4.0 International license.

Table 3. Simplified lapatinib analogs 27-34.

\begin{tabular}{|c|c|c|c|c|c|c|c|}
\hline \multirow{2}{*}{ Cmpd } & \multirow{2}{*}{$\mathbf{x}$} & \multirow{2}{*}{$\mathbf{R}^{1}$} & \multirow{2}{*}{$\mathbf{R}^{2}$} & \multirow{2}{*}{$\mathbf{R}^{3}$} & \multirow{2}{*}{$\mathrm{R}^{4}$} & PKN3 $^{a}$ & EGFR \\
\hline & & & & & & ${ }^{I} C_{50}(\mu \mathrm{M})$ & in-cell IC $\mathrm{C}_{50}(\mu \mathrm{M})$ \\
\hline Lapatinib & $\mathrm{CH}$ & $\mathrm{OCH}_{3}$ & $\mathrm{OCH}_{3}$ & $\mathrm{Cl}$ & $A$ & 5.9 & $0.021^{\mathrm{b}}$ \\
\hline 27 & $\mathrm{CH}$ & $\mathrm{OCH}_{3}$ & $\mathrm{OCH}_{3}$ & $\mathrm{Cl}$ & A & 8.2 & $1.7^{\mathrm{b}}$ \\
\hline 28 & $\mathrm{~N}$ & $\mathrm{OCH}_{3}$ & $\mathrm{OCH}_{3}$ & $\mathrm{Cl}$ & A & 17 & $0.015^{b}$ \\
\hline 29 & $\mathrm{CH}$ & $\mathrm{OCH}_{3}$ & $\mathrm{OCH}_{3}$ & $\mathrm{OH}$ & B & 38 & $14^{c}$ \\
\hline 30 & $\mathrm{CH}$ & $\mathrm{OCH}_{3}$ & $\mathrm{OCH}_{3}$ & $\mathrm{OH}$ & C & $>50$ & $13^{c}$ \\
\hline 31 & $\mathrm{CH}$ & $\mathrm{OCH}_{3}$ & $\mathrm{OCH}_{3}$ & $\mathrm{H}$ & D & $>50$ & $>20^{\circ}$ \\
\hline 32 & $\mathrm{CH}$ & $\mathrm{OCH}_{3}$ & $\mathrm{OCH}_{3}$ & $\mathrm{H}$ & $E$ & $>50$ & $>20^{c}$ \\
\hline 33 & $\mathrm{CH}$ & $\mathrm{OCH}_{3}$ & $\mathrm{H}$ & $\mathrm{OH}$ & $B$ & $>50$ & $14^{c}$ \\
\hline 34 & $\mathrm{CH}$ & $\mathrm{H}$ & $\mathrm{OCH}_{3}$ & $\mathrm{OH}$ & $B$ & 11 & $6.3^{c}$ \\
\hline
\end{tabular}

${ }^{a} C_{50}$ values generated in SLCA assay $(n=2)^{[29-30]}$; bin-cell assay as previously reported ${ }^{[33]}$; cin-cell assay as Previously reported ${ }^{[36]}$

Table 4. Results of halogenated quinolines 35-39.

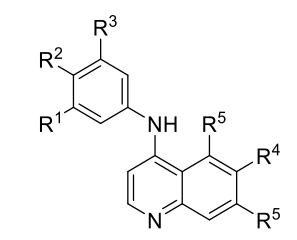

\begin{tabular}{|c|c|c|c|c|c|c|c|}
\hline \multirow{2}{*}{ Cmpd } & \multirow{2}{*}{$\mathbf{R}^{1}$} & \multirow{2}{*}{$\mathbf{R}^{2}$} & \multirow{2}{*}{$\mathbf{R}^{3}$} & \multirow{2}{*}{$\mathbf{R}^{4}$} & \multirow{2}{*}{$\mathbf{R}^{5}$} & PKN3 $^{a}$ & $\mathbf{G A K}^{\mathrm{b}}$ \\
\hline & & & & & & $\mathrm{IC}_{50}(\mu \mathrm{M})$ & in-cell IC $C_{50}(\mu \mathrm{M})$ \\
\hline 35 & $\mathrm{~F}$ & $\mathrm{~F}$ & $\mathrm{~F}$ & $\mathrm{CF}_{3}$ & $\mathrm{H}$ & 2.3 & $>5$ \\
\hline 36 & $\mathrm{~F}$ & $\mathrm{~F}$ & $\mathrm{~F}$ & $\mathrm{Br}$ & $\mathrm{H}$ & 2.2 & 3.7 \\
\hline 37 & $\mathrm{H}$ & $\mathrm{F}$ & $\mathrm{F}$ & $\mathrm{Br}$ & $\mathrm{H}$ & 3.2 & $>5$ \\
\hline 38 & $\mathrm{H}$ & $\mathrm{Cl}$ & $\mathrm{F}$ & $\mathrm{CF}_{3}$ & $\mathrm{H}$ & 1.2 & 4.0 \\
\hline 39 & $\mathrm{OCH}_{3}$ & $\mathrm{OCH}_{3}$ & $\mathrm{OCH}_{3}$ & $\mathrm{H}$ & $\mathrm{F}$ & 0.56 & 4.4 \\
\hline
\end{tabular}

${ }^{a} C_{50}$ values generated in SLCA assay $(n=2)^{[29-30]}$; in-cell $I_{50}$ values obtained in NanoBRET assay and previously reported, ${ }^{[31-33,35]}$ assay as previously described. ${ }^{[31]}$

The 7-iodo quinoline (16) was the most potent derivative with an $\mathrm{IC}_{50}$ of $1.3 \mu \mathrm{M}$. However, compound 16 revealed significant GAK activity in cells with a bias of just over 17 -fold.

In order to model PKN3 we assessed the sequence similarity of studied PKN3 kinase to closely related PKN1 and PKN2. The same kinase family has a high homology (PKN3 vs PKN1 66\% and PKN3 vs PKN2 57\%), and these kinases are also closely related in the kinome phylogenetic tree. ${ }^{[39]}$ When comparing the experimental $\mathrm{x}$-ray structures of the PKN1 and PKN2 kinase domains, their overall folding is almost identical (Figure S1). This suggests that homology modelling should result in reasonable structural quality. This homology model is especially valuable in since a protein crystal structure of PKN3 is not available. Experimental structures of PKN1 provide information about the apo structure, but also about the binding mode of several co-crystallized inhibitors including lestaurtinib and bisindolylmaleimide. ${ }^{[40]}$ The $x$-ray structure of PRK1 provides information that the HOLO form of both PKN1 and PRK1 that have similar to inhibitor binding modes. ${ }^{[41]}$

Our docking studies using the PKN3 homology model suggest that the quinoline scaffold adopts a similar binding conformation as in EGFR and NAK family kinases as previously reported (Figure 3). ${ }^{[30]}$ The quinoline scaffold binds to the hinge region via $\mathrm{H}$-bond interactions between the amide of Val642 and two weaker aromatic hydrogen bonds to the carbonyl group of Glu640 and Val642. The trimethoxyaniline moiety of 16 accommodates the hydrophobic pocket and forms a a hydrogen bond interaction with the catalytic lysine (Lys588) (Figure 3C).

Small-molecule $\mathrm{x}$-ray structures were determined for $\mathbf{5 2}$, 54 and 57 (Figure 4). ${ }^{[42-44]}$ This highlighted the influence of the fluorine on the distal part of the aniline ring system.

\section{Discussion}

Protein kinases present promising drug targets shown by more than 45 inhibitors targeting the ATP binding site of kinases that have been approved for use in the clinic. ${ }^{[45]}$ However, the high clinical efficacy of most of these drugs is based on binding to the conserved ATP binding pocket of more than one kinase. ${ }^{[46]}$ The use of these multi-kinase inhibitors is limited to oncology indications. Inhibitors with significantly improved potency and selectivity profiles are needed for the development of compounds for new treatments outside of oncology. ${ }^{[4]}$ In order to develop those compounds novel approaches are urgently required. 
bioRxiv preprint doi: https://doi.org/10.1101/2020.03.02.972943; this version posted March 3, 2020. The copyright holder for this preprint (which was not certified by peer review) is the author/funder, who has granted bioRxiv a license to display the preprint in perpetuity. It is made available under aCC-BY-NC 4.0 International license.

Table 5. Investigation of matched pairs of para-substituted quinolines.

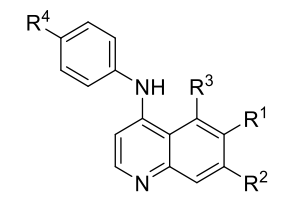

\begin{tabular}{|c|c|c|c|c|c|}
\hline \multirow{2}{*}{ Cmpd } & \multirow{2}{*}{$\mathbf{R}^{1}$} & \multirow{2}{*}{$\mathbf{R}^{2}$} & \multirow{2}{*}{$\mathbf{R}^{3}$} & \multirow{2}{*}{$\mathbf{R}^{4}$} & PKN3 $^{a}$ \\
\hline & & & & & $\%$ control remaining at $1 \mu \mathrm{M}$ \\
\hline Lapatinib & $\mathrm{OCH}_{3}$ & $\mathrm{OCH}_{3}$ & $\mathrm{H}$ & - & $\mathrm{IC}_{50}=5.9 \mu \mathrm{M}$ \\
\hline 40 & $\mathrm{OCH}_{3}$ & $\mathrm{OCH}_{3}$ & $\mathrm{H}$ & & 100 \\
\hline 41 & $\mathrm{Br}$ & $\mathrm{H}$ & $\mathrm{H}$ & & 99 \\
\hline 42 & $\mathrm{H}$ & $\mathrm{F}$ & $\mathrm{F}$ & & 100 \\
\hline 43 & $\mathrm{OCH}_{3}$ & $\mathrm{OCH}_{3}$ & $\mathrm{H}$ & & 97 \\
\hline 44 & $\mathrm{Br}$ & $\mathrm{H}$ & $\mathrm{H}$ & & 100 \\
\hline 45 & $\mathrm{H}$ & $\mathrm{F}$ & $\mathrm{F}$ & & 100 \\
\hline 46 & $\mathrm{OCH}_{3}$ & $\mathrm{OCH}_{3}$ & $\mathrm{H}$ & & 93 \\
\hline 47 & $\mathrm{Br}$ & $\mathrm{H}$ & $\mathrm{H}$ & & 100 \\
\hline 48 & $\mathrm{H}$ & $\mathrm{F}$ & $\mathrm{F}$ & & 100 \\
\hline 49 & $\mathrm{OCH}_{3}$ & $\mathrm{OCH}_{3}$ & $\mathrm{H}$ & & 92 \\
\hline 50 & $\mathrm{Br}$ & $\mathrm{H}$ & $\mathrm{H}$ & & 93 \\
\hline 51 & $\mathrm{H}$ & $\mathrm{F}$ & $\mathrm{F}$ & & 100 \\
\hline 52 & $\mathrm{OCH}_{3}$ & $\mathrm{OCH}_{3}$ & $\mathrm{H}$ & & 73 \\
\hline 53 & $\mathrm{Br}$ & $\mathrm{H}$ & $\mathrm{H}$ & & 100 \\
\hline 54 & $\mathrm{OCH}_{3}$ & $\mathrm{OCH}_{3}$ & $\mathrm{H}$ & & 93 \\
\hline 55 & $\mathrm{Br}$ & $\mathrm{H}$ & $\mathrm{H}$ & & 91 \\
\hline 56 & $\mathrm{OCH}_{3}$ & $\mathrm{OCH}_{3}$ & $\mathrm{H}$ & & 79 \\
\hline 57 & $\mathrm{Br}$ & $\mathrm{H}$ & $\mathrm{H}$ & & 95 \\
\hline
\end{tabular}

a SLCA Assay $(\mathrm{n}=2)^{[29-30]}$

Table 6. PKN3 NanoBRET results of the most potent analogs.<smiles>[R]c1cc2nccc(Nc3cc(OC)c(OC)c(OC)c3)c2cc1[R]</smiles>

\begin{tabular}{c|c|c|c}
\hline \multirow{2}{*}{ Cmpd } & \multirow{2}{*}{$\mathbf{R}^{\mathbf{1}}$} & \multirow{2}{*}{$\mathbf{R}^{\mathbf{2}}$} & PKN3 $^{\text {a }}$ \\
\cline { 4 - 4 } & & & in-cell IC 50 $(\mu \mathrm{M})$ \\
\hline $\mathbf{8}$ & $\mathrm{Cl}$ & $\mathrm{H}$ & 6.5 \\
$\mathbf{9}$ & $\mathrm{Br}$ & $\mathrm{H}$ & 3.5 \\
$\mathbf{1 0}$ & $\mathrm{I}$ & $\mathrm{H}$ & $>10$ \\
$\mathbf{1 4}$ & $\mathrm{H}$ & $\mathrm{Cl}$ & $>10$ \\
$\mathbf{1 5}$ & $\mathrm{H}$ & $\mathrm{Br}$ & 2.7 \\
$\mathbf{1 6}$ & $\mathrm{H}$ & $\mathrm{I}$ & 1.3
\end{tabular}

One possible tool amongst others to achieve kinase inhibitors with improved selectivity is the usage of binding assays as a rapid, accurate and robust method to assess potency and potentially wider selectivity of ATP-competitive kinase inhibitors. ${ }^{[47-48]}$ Furthermore, these ligand binding displacement assays provide an accepted direct measurement of kinase inhibition in drug optimization of ATP binding site inhibitors. ${ }^{[49-50]}$ This is a particularly acute point in the case of more neglected kinases such as PKN3 and GAK where there are currently no robust and validated enzyme activity assays available.

In order to not only measure the binding of the synthesized compounds in the isolated enzyme but also in cell the NanoBRET assay presents an excellent technique to measure the target engagement in human cells. Other reported mass spectrometry (MS)-based chemoproteomics approaches rely on the disruption of the plasma membrane and therefore suffer from dissolution of key cellular cofactors like ATP. In contrast, the NanoBRET assay is performed in intact cells. As a result, additionally to be a competitive binder of the ATP binding site the compound needs to be cell permeable in order to be detected by the NanoBRET assay. The cellular thermal shift assay (CETSA) uses intact cells 
bioRxiv preprint doi: https://doi.org/10.1101/2020.03.02.972943; this version posted March 3, 2020. The copyright holder for this preprint (which was not certified by peer review) is the author/funder, who has granted bioRxiv a license to display the preprint in perpetuity. It is made available under aCC-BY-NC 4.0 International license.
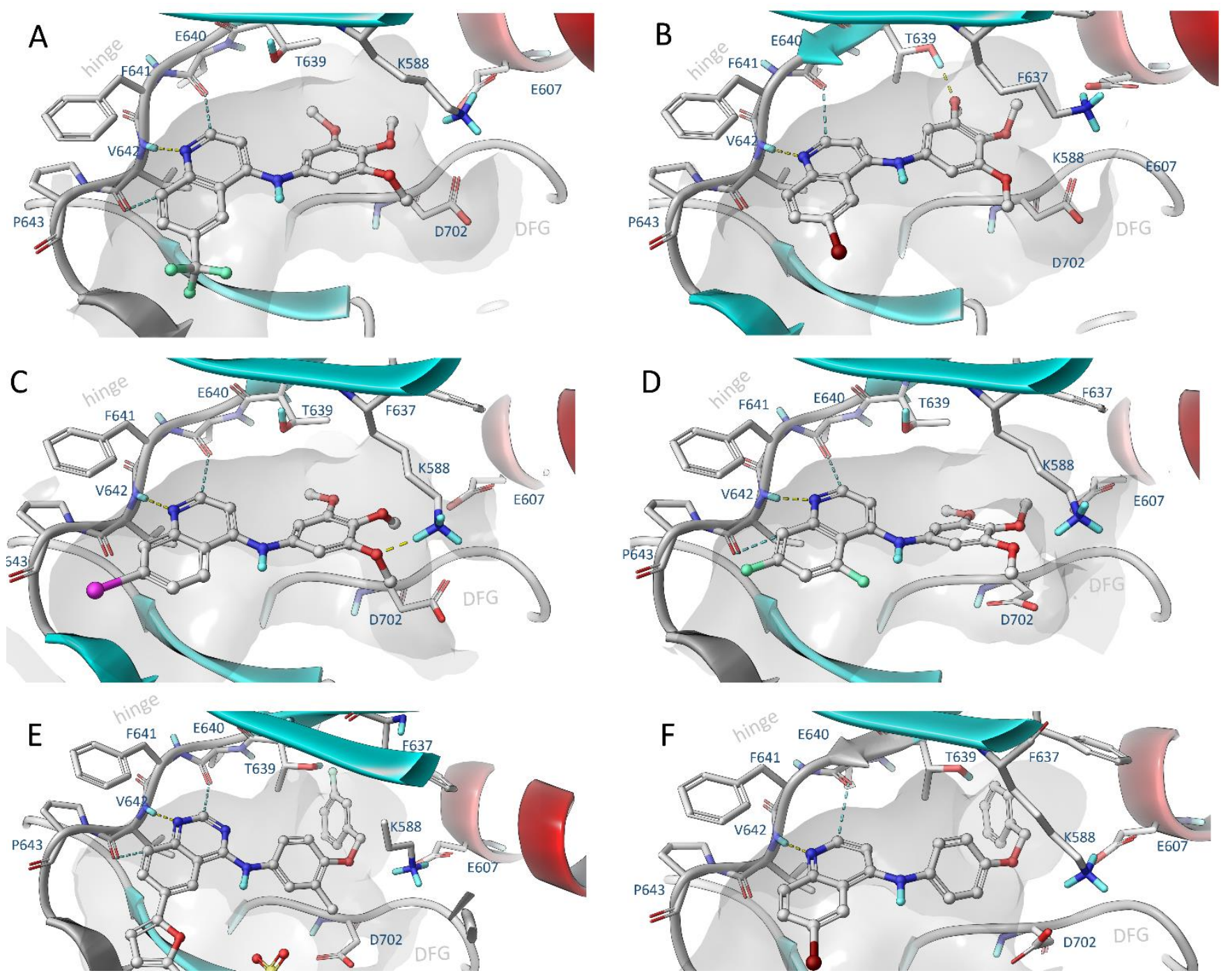

Figure 3. Induced fit docking of selected compounds $2(A), 9(B), 16(C), 39(D)$, lapatinib (E) and $\mathbf{5 0}(F)$ to PKN3 made by means of comparative modelling using high homologue templates (65\%, PDB: 4OTG, 4OTH).

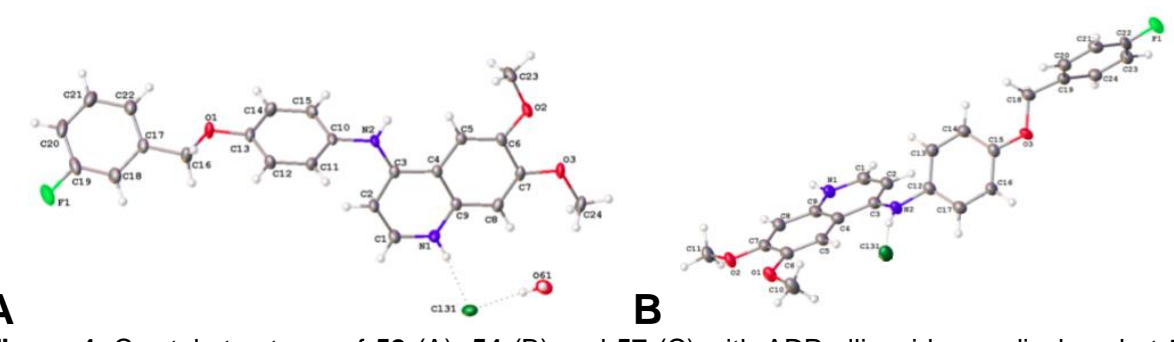

Figure 4. Crystal structures of 52 (A), 54 (B) and 57 (C) with ADP ellipsoids are displayed at $50 \%$ probability. Counter ions are shown but solvent molecules are not shown for clarity. Structure A contains two independent molecules per asymmetric unit, only one is shown for clarity.

as well. However, CETSA does not quantify the equilibrium-based inhibitor occupancy in contrast to the NanoBRET assay. ${ }^{[37-38]}$ Therefore, the NanoBRET assay was used to determine the incell potency of the synthesized PKN3 inhibitors.

Encouraging results from initial PKIS2 screening and literature inhibitors demonstrated the potential of the 4anilinoquin(az)oline scaffold. We explored several series of substitution patterns around the quin(az)oline core including trimethoxy and hybrid lapatinib derivatives. While strategies were employed to remove key collateral kinase targets including GAK and EGFR they were ultimately only partly successful. The trimethoxy compounds were the most potent compounds on PKN3 with 8, 9, 15 and $\mathbf{1 6}$ being the most potent overall in SLCA assay and in cells. We were able to identify 16 as a potent compound against PKN3 with and $\mathrm{IC}_{50}$ of $1.3 \mu \mathrm{M}$ in cells. While several of these quinoline based analogs have been shown to be narrow spectrum across the wider kinome including $\mathbf{2}$ and $\mathbf{9}$. Compound $\mathbf{1 6}$ presents a useful potential tool compound to study PKN3 biology. However, further optimization could yield a more potent analog within this series or from the kinase inhibitor landscape.

Our modelling studies with lapatinib and its structure related PKN3 inhibitors suggest that PKN3 may have a more flexible back pocket area. This may give additional structural freedom for further modification of active scaffolds to improve selectivity over GAK and EGFR. However, homology-based docking poses are 
bioRxiv preprint doi: https://doi.org/10.1101/2020.03.02.972943; this version posted March 3, 2020. The copyright holder for this preprint (which was not certified by peer review) is the author/funder, who has granted bioRxiv a license to display the preprint in perpetuity. It is made available under aCC-BY-NC 4.0 International license.

heavily reflected by structural features derived from template kinases and further structural biology studies with structurally related inhibitors are needed to confirm and validate current docking models.

Taken together this library of compounds provides further evidence that PKN3 can be targeted consistently by a series of small molecule inhibitors. Quinoline-based ATP-competitive kinase inhibitors were designed with high potency in vitro and moderate potency in cells. The 4-anilinoquinoline 16 was identified as a potent PKN3 inhibitor with low micromolar potency in cells. The 4 -anilinoquinolines series exemplified by $\mathbf{2}$ and $\mathbf{1 6}$ has the potential to yield high-quality chemical probes for use in the elucidation of PKN3 function in cells, and perhaps in vivo.

\section{Experimental Section}

\section{Modelling methods}

PKN3 is structurally closely related with other proteins of the serine/threonine protein kinase folding family. ${ }^{[51]}$ The sequence homology to known template structures is feasible $66 \%$ - so as a consequence a homology modelling approach was conducted. The PKN3 model was constructed using structure prediction wizard of Maestro 2019.4. At the first stage a blast search was carried out in order to find suitable template structures. Sequences taken from crystal structures of PRK1 Catalytic Domain (PDB: 4OTD, 4OTG, 4OTH, 4OTI) and Human Protein Kinase N2 (PDB: 4CRS) were used for pairwise sequence alignment using clustalW methodology, which is suitable in this case, due to the structural similarity. High resolution structure, PDB:4OTH was selected as template for comparative modelling (identity $66 \%$, positives $80 \%$, alignment length 337 (kinase domain), resolution 1.8 $\AA$ ). Due to the good sequence similarity, a homology model was constructed using knowledge-based approach of the wizard employing multi template approach, where the model was mainly constructed based on PDB:4OTH, including ligand occupying the ATP binding pocket. The missing activation loop of PDB:4OTH was modeled based on other PDB structure of the same template (PDB:4OTG). Loop refinement was run to optimize the structure of $C$-terminal end.

Prior to docking studies, the homology model of the PKN3 structure was pre-processed by using the protein preparation wizard tool of Schrödinger Suite 2019-4 (Protein Preparation Wizard uses modules: Epik; Impact and Prime, Schrödinger, LLC, New York, NY, 2019). Structures of small molecule ligands were parametrized and minimized using Ligprep module (LigPrep, Schrödinger, LLC, New York, NY, 2019.). Molecular docking studies were computed using Induced fit workflow of Schrödinger employing SP-setting for Glide docking module and side chain $5 \AA$ were consider for conformational refinement using Prime module. Hydrogen bond constraint was added to hinge residue VAL642 to improved convergence of docking poses. Results were consistent with co-crystal binding modes in other kinases, eg GAK and the 4-anilinoquin(az)oline gefitinib. ${ }^{[52]}$

\section{Biology}

SLCA Method: The split-luciferase kinase assays were performed by Luceome Biotechnologies. Briefly, split-firefly luciferase constructs were translated and assayed in cell-free system according to literature protocol. ${ }^{[29,30]}$ Data were collected via a homogeneous competition binding assay where the displacement of an active site dependent probe by an inhibitor is measured by a change in luminescence signal. Testing was performed with either DMSO (no-inhibitor control) or a compound solution in DMSO, followed by incubation in the presence of a kinase specific probe. Luminescence was measured upon addition of a luciferin assay reagent to each assay solution. All PKIS2 library members and SAR analogs were screened at $1 \mu \mathrm{M}$ in duplicate against PKN3. $I_{50}$ values (8-point dose response format) were determined by plotting percent activity remaining against inhibitor concentration.

NanoBRET method. Cell Transfections and BRET Measurements: $N$-terminal NanoLuc/Kinase fusions were encoded in $\mathrm{pFN} 31 \mathrm{~K}$ or pFC32K expression vectors (Promega), including flexible Gly-Ser-Ser-Gly linkers between Nluc and each full-length kinase. For cellular BRET target engagement experiments, HEK-293 cells were transfected with NLuc/target fusion constructs using FuGENE HD (Promega) according to the manufacturer's protocol. Briefly, Nluc/target fusion constructs were diluted into Opti-MEM followed by Transfection Carrier DNA (Promega) at a mass ratio of $1: 10$ (mass/mass), after which FuGENE HD was added at a ratio of 1:3 (mg DNA: mL FuGENE HD). 1 part (vol) of FuGENE HD complexes thus formed were combined with 20 parts (vol) of HEK-293 cells in DMEM with $10 \%$ FBS plated at a density of $2 \times 10^{5}$ per $\mathrm{mL}$ into 96 -well plates (Corning), followed by incubation in a humidified, $37^{\circ} \mathrm{C} / 5 \% \mathrm{CO}_{2}$ incubator for 20-30 hr. BRET assays were performed in white, 96well cell culture treated plates (Corning) at a density of $2 \times 104$ cells/well.

Following transfection, DMEM was exchanged for Opti-MEM. All chemical inhibitors were prepared as concentrated stock solutions in DMSO (Sigma-Aldrich) and diluted in Opti-MEM (unless otherwise noted) to prepare working stocks. Cells were equilibrated for $2 \mathrm{~h}$ with energy transfer probes and test compound prior to BRET measurements. Energy transfer probes were prepared at a working concentration of $20 \mathrm{X}$ in tracer dilution buffer (12.5 mM HEPES, 31.25\% PEG-400, pH 7.5). For target engagement analysis, the energy transfer probes were added to the cells at concentrations optimized for each target. For analysis of PKN3-NL, energy transfer probe K-5 was used at a final concentration of $1000 \mathrm{nM}$. To measure BRET, NanoBRET NanoGlo Substrate and Extracellular NanoLuc Inhibitor (Promega) were added according to the manufacturer's recommended protocol, and filtered luminescence was measured on a GloMax Discover luminometer equipped with $450 \mathrm{nM}$ BP filter (donor) and $600 \mathrm{nM}$ LP filter (acceptor), using $0.5 \mathrm{~s}$ integration time. Milli-BRET units (mBU) are calculated by multiplying the raw BRET values by 1000 . Competitive displacement data were plotted with GraphPad Prism software and data were fit to Equation 1 [ $\log$ (inhibitor) vs. response -Variable slope (four parameters)] to determine the $I_{50}$ value; $Y=$ Bottom + (Top-Bottom $) /\left(1+10^{\wedge}\left(\left(\text { LoglC }_{50}-\mathrm{X}\right)^{\star}\right.\right.$ HillSlope $\left.)\right)$. (Equation 1).

If the curve was insufficiently described by the raw data, then they were normalized to the controls-BRET in the presence of only energy transfer probe, and BRET in the absence of the energy transfer probe and test compound-then plotted to fit Equation 2 [log(inhibitor) vs. normalized response -- Variable slope] to determine the $\mathrm{IC}_{50}$ value; $\mathrm{Y}=100 /\left(1+10^{\wedge}\left(\left(\mathrm{LoglC}_{50}-\mathrm{X}\right)^{\star} \mathrm{Hill}\right.\right.$ Slope $\left.\left.)\right)\right)$. (Equation 2). For all BRET data shown, no individual data points were omitted.

\section{Chemistry}

General Procedure: 4-chloroquinoline derivative (150 mg $0.67 \mathrm{mmol})$ and aniline $(0.74 \mathrm{mmol})$ was suspended in ethanol $(10 \mathrm{~mL})$ and heated to reflux for $16 \mathrm{~h}$. The crude mixture was purified by flash chromatography using EtOAc/hexane followed by $1-5 \%$ methanol in EtOAc (or by re-crystallization). After solvent removal under reduced pressure, the product was obtained. All compounds were $>98 \%$ pure by ${ }^{1} \mathrm{H} /{ }^{13} \mathrm{C}$ NMR and LCMS. Compounds 2 and 4-39 were prepared as previously described. ${ }^{[35}$, $36,53]$

Automated flash chromatography: Isolera ${ }^{\mathrm{TM}}$ Prime, Version 3.0 (Biotage $^{\circledR}$ ); RediSep ${ }^{\circledR}$ Rf columns (Teledyne ISCO ${ }^{\mathrm{TM}}$ ), normalphase, prepacked, $5 \mathrm{~g}$; parentheses include: cartridge size, flow 
bioRxiv preprint doi: https://doi.org/10.1101/2020.03.02.972943; this version posted March 3, 2020. The copyright holder for this preprint (which was not certified by peer review) is the author/funder, who has granted bioRxiv a license to display the preprint in perpetuity. It is made available under aCC-BY-NC 4.0 International license.

rate, eluent, fractions size was always $12 \mathrm{~mL}$. The crude mixture was purified by automatic flash chromatography $(5 \mathrm{~g}$ column, flowrate: $6 \mathrm{ml} / \mathrm{min}, n$-hexane $\rightarrow n$-hexane : ethyl acetate 80:20 $\rightarrow$ ethyl acetate $\rightarrow$ ethyl acetate : methanol $=90: 10$ ) and the solvent was evaporated under reduced pressure to yield the title compound.

\section{$\mathrm{N}$-(4-Ethoxyphenyl)-6,7-dimethoxyquinolin-4-amine}

(40):

prepared as decribed with an additional washing step of ether $(10 \mathrm{~mL})$ to cause the precipitation of the crude product prior to filtration to afford a mustard solid (198 $\mathrm{mg}, 0.610 \mathrm{mmol}, 91 \%$ ); m.p. $241^{\circ} \mathrm{C} ;{ }^{1} \mathrm{H}$ NMR $\left(400 \mathrm{MHz},\left[\mathrm{D}_{6}\right.\right.$ ]DMSO) $\delta 10.60(\mathrm{~s}, 1 \mathrm{H}), 8.28$ $(\mathrm{d}, J=6.9 \mathrm{~Hz}, 1 \mathrm{H}), 8.16(\mathrm{~s}, 1 \mathrm{H}), 7.46(\mathrm{~s}, 1 \mathrm{H}), 7.40-7.31(\mathrm{~m}, 2 \mathrm{H})$, $7.13-7.04(\mathrm{~m}, 2 \mathrm{H}), 6.54(\mathrm{~d}, J=6.9 \mathrm{~Hz}, 1 \mathrm{H}), 4.08(\mathrm{q}, J=6.9 \mathrm{~Hz}$, $2 \mathrm{H}), 3.99(\mathrm{~s}, 3 \mathrm{H}), 3.96(\mathrm{~s}, 3 \mathrm{H}), 1.36 \mathrm{ppm}(\mathrm{t}, J=6.9 \mathrm{~Hz}, 3 \mathrm{H}) ;{ }^{13} \mathrm{C}$ NMR (101 MHz, [D 6 ]DMSO) $\delta 157.4,154.4,153.5,149.3,139.8$, 135.4, 129.9, 127.2, 115.5, 111.3, 102.7, 100.0, 98.7, 63.4, 56.7, 56.1, $14.6 \mathrm{ppm}$; HRMS-ESI (m/z): $[\mathrm{M}+\mathrm{H}]^{+}$calcd for $\mathrm{C}_{19} \mathrm{H}_{21} \mathrm{~N}_{2} \mathrm{O}_{3}{ }^{+}$ 325.1547 , found 325.1543 ; $L C: t_{R}=3.84 \mathrm{~min}$, purity $>98 \%$.

6-Bromo- $\mathrm{N}$-(4-ethoxyphenyl)quinolin-4-amine (41): was obtained as a light brown solid (197 mg, $0.572 \mathrm{mmol}, 93 \%$ ); m.p. $151{ }^{\circ} \mathrm{C} ;{ }^{1} \mathrm{H}$ NMR $\left(400 \mathrm{MHz},\left[\mathrm{D}_{6}\right] \mathrm{DMSO}\right) \delta 10.98(\mathrm{~s}, 1 \mathrm{H}), 9.13(\mathrm{~d}$ $J=2.0 \mathrm{~Hz}, 1 \mathrm{H}), 8.48(\mathrm{~d}, J=7.0 \mathrm{~Hz}, 1 \mathrm{H}), 8.15(\mathrm{dd}, J=9.0,2.0 \mathrm{~Hz}$, $1 \mathrm{H}), 8.05(\mathrm{~d}, J=9.0 \mathrm{~Hz}, 1 \mathrm{H}), 7.40-7.34(\mathrm{~m}, 2 \mathrm{H}), 7.14-7.08(\mathrm{~m}$, 2H), $6.68(\mathrm{~d}, J=7.0 \mathrm{~Hz}, 1 \mathrm{H}), 4.09(\mathrm{q}, J=7.0 \mathrm{~Hz}, 2 \mathrm{H}), 1.36 \mathrm{ppm}$ $(\mathrm{t}, J=7.0 \mathrm{~Hz}, 3 \mathrm{H}) \cdot{ }^{13} \mathrm{C} \mathrm{NMR}\left(101 \mathrm{MHz},\left[\mathrm{D}_{6}\right] \mathrm{DMSO}\right) \delta 157.7,154.4$, $142.8,137.3,136.5,129.3,127.0,126.1,122.4,119.7,118.4$, 115.6, 100.1, 63.4, $14.6 \mathrm{ppm}$; HRMS-ESI $(\mathrm{m} / \mathrm{z}):[\mathrm{M}+\mathrm{H}]^{+}$calcd for $\mathrm{C}_{17} \mathrm{H}_{16} \mathrm{BrN}_{2} \mathrm{O}^{+}$343.0441, found 343.0440; LC: $t_{\mathrm{R}}=3.97 \mathrm{~min}$, purity $>98 \%$.

$N$-(4-Ethoxyphenyl)-5,7-difluoroquinolin-4-amine (42): was prepared on a larger scale (4-chloro-5,7-difluoroquinoline (500 mg, $2.51 \mathrm{mmol})$ and aniline $(2.76 \mathrm{mmol})$ and additional following washing steps with ethyl acetate and a mixture of ethyl acetate/methanol 9:1) to afford a bright yellow solid (153 mg, 0.509 mmol, $20 \%$ ); m.p. $238{ }^{\circ} \mathrm{C} ;{ }^{1} \mathrm{H}$ NMR (400 MHz, [D 6 ]DMSO) $\delta 10.22(\mathrm{~d}, J=11.8 \mathrm{~Hz}, 1 \mathrm{H}), 8.42(\mathrm{~d}, J=7.2 \mathrm{~Hz}, 1 \mathrm{H}), 7.79$ (dd, $J$ $=12.7,9.1 \mathrm{~Hz}, 2 \mathrm{H}), 7.38-7.32(\mathrm{~m}, 2 \mathrm{H}), 7.14-7.08(\mathrm{~m}, 2 \mathrm{H}), 6.50$ (d, $J=7.1 \mathrm{~Hz}, 1 \mathrm{H}), 4.09(\mathrm{q}, J=6.9 \mathrm{~Hz}, 2 \mathrm{H}), 1.36 \mathrm{ppm}(\mathrm{t}, J=6.9$ $\mathrm{Hz}, 3 \mathrm{H}) ;{ }^{13} \mathrm{C}$ NMR $\left(101 \mathrm{MHz},\left[\mathrm{D}_{6}\right] \mathrm{DMSO}\right) \delta 164.1$ (dd, $J=253.3$ $15.6 \mathrm{~Hz}$ ), 160.7 (dd, $J=254.2,15.3 \mathrm{~Hz}$ ), 158.6, 155.3 (d, $J=3.3$ $\mathrm{Hz}$ ), 143.5, 141.4 (dd, $J=15.1,6.5 \mathrm{~Hz}), 129.9,128.4,116.1$, 105.67 (dd, $J=13.4,2.2 \mathrm{~Hz}), 104.3-103.2(\mathrm{~m}), 102.1$ (dd, $J=$ 25.3, $4.5 \mathrm{~Hz}), 101.4,63.9,15.1 \mathrm{ppm}$. HRMS-ESI $(\mathrm{m} / \mathrm{z}):[\mathrm{M}+\mathrm{H}]^{+}$ calcd for $\mathrm{C}_{17} \mathrm{H}_{15} \mathrm{~F}_{2} \mathrm{~N}_{2} \mathrm{O}^{+}$301.1147, found 301.1147; LC: $t_{R}=3.69$ min, purity $>98 \%$.

\section{N-(4-Isopropoxyphenyl)-6,7-dimethoxynaphthalen-1-amine} (43): was obtained as a light yellow solid $(195 \mathrm{mg}, 0.578 \mathrm{mmol}$, $86 \%$ ); m.p. $209^{\circ} \mathrm{C} ;{ }^{1} \mathrm{H}$ NMR $\left(400 \mathrm{MHz},\left[\mathrm{D}_{6}\right] \mathrm{DMSO}\right) \delta 10.52$ (s, $1 \mathrm{H}), 8.28(\mathrm{~d}, J=6.9 \mathrm{~Hz}, 1 \mathrm{H}), 8.13(\mathrm{~s}, 1 \mathrm{H}), 7.44(\mathrm{~s}, 1 \mathrm{H}), 7.39-$ $7.30(\mathrm{~m}, 2 \mathrm{H}), 7.11-7.03(\mathrm{~m}, 2 \mathrm{H}), 6.56(\mathrm{~d}, J=6.9 \mathrm{~Hz}, 1 \mathrm{H}), 4.67$ (hept, $J=6.0 \mathrm{~Hz}, 1 \mathrm{H}), 3.99(\mathrm{~s}, 3 \mathrm{H}), 3.96(\mathrm{~s}, 3 \mathrm{H}), 1.31(\mathrm{~s}, 3 \mathrm{H})$, $1.30 \mathrm{ppm}(\mathrm{s}, 3 \mathrm{H}) ;{ }^{13} \mathrm{C}$ NMR $\left(101 \mathrm{MHz},\left[\mathrm{D}_{6}\right] \mathrm{DMSO}\right) \delta 156.3,154.3$, 153.4, 149.2, 140.1, 135.7, 129.8, 127.2, 116.6, 111.4, 102.6, 100.3, 98.8, 69.5, 56.6, 56.1, 21.8 ppm; HRMS-ESI $(\mathrm{m} / \mathrm{z}):[\mathrm{M}+\mathrm{H}]^{+}$ calcd for $\mathrm{C}_{21} \mathrm{H}_{24} \mathrm{NO}_{3}{ }^{+}$338.4265, found 339.1700; LC: $t_{R}=4.04$ min, purity $>98 \%$.

6-Bromo- $\mathrm{N}$-(4-isopropoxyphenyl)quinolin-4-amine (44): was obtained as a light brown solid (107 mg, $0.299 \mathrm{mmol}, 48 \%$ ); m.p. $149^{\circ} \mathrm{C} ;{ }^{1} \mathrm{H}$ NMR $(400 \mathrm{MHz}$, [D 6 DMSO) $\delta 10.86(\mathrm{~s}, 1 \mathrm{H}), 9.09(\mathrm{~d}$, $J=2.0 \mathrm{~Hz}, 1 \mathrm{H}), 8.45(\mathrm{~d}, J=6.9 \mathrm{~Hz}, 1 \mathrm{H}), 8.12(\mathrm{dd}, J=9.0,2.0 \mathrm{~Hz}$, $1 \mathrm{H}), 8.02(\mathrm{~d}, J=9.0 \mathrm{~Hz}, 1 \mathrm{H}), 7.37-7.31(\mathrm{~m}, 2 \mathrm{H}), 7.10-7.04(\mathrm{~m}$, 2H), 6.68 (d, $J=6.9 \mathrm{~Hz}, 1 \mathrm{H}$ ), 4.66 (hept, $J=6.0 \mathrm{~Hz}, 1 \mathrm{H}$ ), 1.30 (s, $3 \mathrm{H}), 1.28 \mathrm{ppm}(\mathrm{s}, 3 \mathrm{H}) ;{ }^{13} \mathrm{C}$ NMR $\left(101 \mathrm{MHz},\left[\mathrm{D}_{6}\right] \mathrm{DMSO}\right) \delta 156.6$, $154.1,143.2,137.8,136.3,129.3,126.9,126.0,122.9,119.6$, 118.5, 116.6, 100.2, 69.6, 21.8 ppm; HRMS-ESI $(\mathrm{m} / \mathrm{z}):[\mathrm{M}+\mathrm{H}]^{+}$ calcd for $\mathrm{C}_{18} \mathrm{H}_{18} \mathrm{BrN}_{2} \mathrm{O}^{+}$357.0597, found 357.0603; LC: $t_{R}=4.55$ min, purity $>98 \%$.

6-Bromo- $\mathrm{N}$-(4-cyclobutoxyphenyl)quinolin-4-amine (45): was prepared on a larger scale (6-bromo-4-chloroquinoline $(500 \mathrm{mg}$, $2.51 \mathrm{mmol})$ and aniline $(2.76 \mathrm{mmol}))$ and additional following washing steps with ethyl acetate and a mixture of ethyl acetate/methanol 9:1) to afford a light yellow solid (232 mg, $0.738 \mathrm{mmol}, 29$ \%); m.p. $236{ }^{\circ} \mathrm{C} ;{ }^{1} \mathrm{H}$ NMR $(400 \mathrm{MHz}$, [D 6 ]DMSO) $\delta 10.21(\mathrm{~d}, J=11.8 \mathrm{~Hz}, 1 \mathrm{H}), 8.42(\mathrm{~d}, J=7.2 \mathrm{~Hz}, 1 \mathrm{H}), 7.85-7.74$ $(\mathrm{m}, 2 \mathrm{H}), 7.37-7.31(\mathrm{~m}, 2 \mathrm{H}), 7.13-7.07(\mathrm{~m}, 2 \mathrm{H}), 6.52(\mathrm{~d}, J=7.1$ $\mathrm{Hz}, 1 \mathrm{H}$ ), 4.68 (hept, $J=6.0 \mathrm{~Hz}, 1 \mathrm{H}), 1.31$ (s, 3H), $1.30 \mathrm{ppm}(\mathrm{s}$, $3 \mathrm{H}) ;{ }^{13} \mathrm{C}$ NMR $\left(101 \mathrm{MHz},\left[\mathrm{D}_{6}\right] \mathrm{DMSO}\right) \delta 163.6(\mathrm{dd}, J=253.3,15.4$ $\mathrm{Hz}$ ), 160.3 (dd, $J=257.9,15.3 \mathrm{~Hz}), 157.1,154.8(\mathrm{~d}, J=3.3 \mathrm{~Hz}$ ), $143.1,140.9$ (dd, $J=15.0,6.6 \mathrm{~Hz}), 129.3,127.9,116.7,105.2$ (dd, $J=13.1,2.2 \mathrm{~Hz}), 103.2$ (dd, $J=28.9,26.8 \mathrm{~Hz}), 101.6$ (dd, $J$ $=25.1,4.3 \mathrm{~Hz}), 101.0,69.6,21.8 \mathrm{ppm}$; HRMS-ESI $(\mathrm{m} / \mathrm{z}):[\mathrm{M}+\mathrm{H}]^{+}$ calcd for $\mathrm{C}_{18} \mathrm{H}_{17} \mathrm{~F}_{2} \mathrm{~N}_{2} \mathrm{O}^{+}$315.1303, found 315.1300; LC: $t_{R}=3.90$ min, purity $>98 \%$.

\section{$\mathrm{N}$-(4-Cyclobutoxyphenyl)-6,7-dimethoxyquinolin-4-amine}

(46): was obtained as a light yellow solid $(170 \mathrm{mg}, 0.485 \mathrm{mmol}$, $72 \%$ ); m.p. $234{ }^{\circ} \mathrm{C} ;{ }^{1} \mathrm{H}$ NMR $\left(400 \mathrm{MHz},\left[\mathrm{D}_{6}\right] \mathrm{DMSO}\right) \delta 10.50$ (s, $1 \mathrm{H}), 8.27(\mathrm{~d}, J=6.8 \mathrm{~Hz}, 1 \mathrm{H}), 8.13(\mathrm{~s}, 1 \mathrm{H}), 7.44(\mathrm{~s}, 1 \mathrm{H}), 7.38-$ $7.30(\mathrm{~m}, 2 \mathrm{H}), 7.04-6.96(\mathrm{~m}, 2 \mathrm{H}), 6.54(\mathrm{~d}, J=6.8 \mathrm{~Hz}, 1 \mathrm{H}), 4.73$ (p, $J=7.0 \mathrm{~Hz}, 1 \mathrm{H}), 3.98(\mathrm{~s}, 3 \mathrm{H}), 3.95(\mathrm{~s}, 3 \mathrm{H}), 2.49-2.41(\mathrm{~m}, 1 \mathrm{H})$, $2.14-2.01(\mathrm{~m}, 2 \mathrm{H}), 1.87-1.75(\mathrm{~m}, 1 \mathrm{H}), 1.73-1.59 \mathrm{ppm}(\mathrm{m}$, $1 \mathrm{H}) ;{ }^{13} \mathrm{C}$ NMR $\left(101 \mathrm{MHz},\left[\mathrm{D}_{6}\right] \mathrm{DMSO}\right) \delta 155.9,154.4,153.5,149.3$, 139.9, 135.5, 130.0, 127.2, 115.8, 111.3, 102.7, 100.1, 98.8, 71.0, 56.7, 56.1, 30.1, $12.8 \mathrm{ppm}$; HRMS-ESI $(\mathrm{m} / \mathrm{z})$ : $[\mathrm{M}+\mathrm{H}]^{+}$calcd for $\mathrm{C}_{21} \mathrm{H}_{23} \mathrm{~N}_{2} \mathrm{O}_{3}+351.1703$, found 351.1697; LC: $\mathrm{t}_{\mathrm{R}}=4.22 \mathrm{~min}$, purity $>98 \%$.

6-Bromo- $\mathrm{N}$-(4-cyclobutoxyphenyl)quinolin-4-amine (47): was obtained as a mustard solid (144 mg, $0.390 \mathrm{mmol}, 46 \%$ ); m.p. $>250{ }^{\circ} \mathrm{C} ;{ }^{1} \mathrm{H}$ NMR $\left(400 \mathrm{MHz},\left[\mathrm{D}_{6}\right] \mathrm{DMSO}\right) \delta 10.98(\mathrm{~s}, 1 \mathrm{H}), 9.14(\mathrm{~d}$ $J=1.8 \mathrm{~Hz}, 1 \mathrm{H}), 8.47(\mathrm{~d}, J=6.9 \mathrm{~Hz}, 1 \mathrm{H}), 8.15(\mathrm{dd}, J=9.0,1.8 \mathrm{~Hz}$, $1 \mathrm{H}), 8.06(\mathrm{~d}, J=9.0 \mathrm{~Hz}, 1 \mathrm{H}), 7.40-7.33(\mathrm{~m}, 2 \mathrm{H}), 7.06-6.98(\mathrm{~m}$, $2 \mathrm{H}), 6.68(\mathrm{~d}, J=6.9 \mathrm{~Hz}, 1 \mathrm{H}), 4.74(\mathrm{p}, J=7.1 \mathrm{~Hz}, 1 \mathrm{H}), 2.49-2.41$ $(\mathrm{m}, 2 \mathrm{H}), 2.14-2.00(\mathrm{~m}, 2 \mathrm{H}), 1.87-1.75(\mathrm{~m}, 1 \mathrm{H}), 1.75-1.58 \mathrm{ppm}$ $(\mathrm{m}, 1 \mathrm{H}) ;{ }^{13} \mathrm{C}$ NMR $\left(101 \mathrm{MHz},\left[\mathrm{D}_{6}\right] \mathrm{DMSO}\right) \delta \mathrm{156.3}, 154.3,142.9$, $137.4,136.4,129.5,127.0,126.1,122.5,119.6,118.4,115.9$ 100.1, 71.0, 30.1, $12.8 \mathrm{ppm}$; calcd for $\mathrm{C}_{19} \mathrm{H}_{18} \mathrm{BrN}_{2} \mathrm{O}^{+} 369.0597$, found 369.0594 ; LC: $t_{R}=4.33$ min, purity $>98 \%$.

\section{6-Bromo- $\mathrm{N}$-(4-cyclobutoxyphenyl)quinolin-4-amine (48): was} obtained as a tan solid (58 mg, $0.178 \mathrm{mmol}, 24 \%$ ); m.p. $238{ }^{\circ} \mathrm{C}$; ${ }^{1} \mathrm{H}$ NMR $\left(400 \mathrm{MHz},\left[\mathrm{D}_{6}\right] \mathrm{DMSO}\right) \delta 10.12(\mathrm{~d}, J=10.4 \mathrm{~Hz}, 1 \mathrm{H}), 8.41$ $(\mathrm{d}, J=7.1 \mathrm{~Hz}, 1 \mathrm{H}), 7.82-7.71(\mathrm{~m}, 2 \mathrm{H}), 7.37-7.29(\mathrm{~m}, 2 \mathrm{H}), 7.05$ $-6.99(\mathrm{~m}, 2 \mathrm{H}), 6.50(\mathrm{~d}, J=7.1 \mathrm{~Hz}, 1 \mathrm{H}), 4.75(\mathrm{p}, J=7.1 \mathrm{~Hz}, 1 \mathrm{H})$ $2.49-2.41(\mathrm{~m}, 2 \mathrm{H}), 2.13-2.00(\mathrm{~m}, 3 \mathrm{H}), 1.87-1.75(\mathrm{~m}, 1 \mathrm{H})$, $1.73-1.59 \mathrm{ppm}(\mathrm{m}, 1 \mathrm{H}) ;{ }^{13} \mathrm{C}$ NMR (101 MHz, [D 6 DMSO) $\delta 163.5$ (dd, $J=253.0,15.5 \mathrm{~Hz}$ ), 160.2 (dd, $J=257.8,15.4 \mathrm{~Hz}$ ), 156.6, $154.6(\mathrm{~d}, J=3.4 \mathrm{~Hz}), 143.6,141.4(\mathrm{dd}, J=15.0,6.2 \mathrm{~Hz}), 129.7$, 127.9, 116.0, $105.3(\mathrm{dd}, J=13.0,2.0 \mathrm{~Hz}), 103.8-102.7(\mathrm{~m})$, 102.0 (dd, $J=24.3,3.3 \mathrm{~Hz}$ ), 101.0, 71.0, 30.0, 12.8 ppm; HRMSESI (m/z): $[\mathrm{M}+\mathrm{H}]^{+}$calcd for $\mathrm{C}_{19} \mathrm{H}_{17} \mathrm{~F}_{2} \mathrm{~N}_{2} \mathrm{O}^{+}$327.1303, found 327.1299; $L C: t_{R}=4.09 \mathrm{~min}$, purity $>98 \%$.

$\mathrm{N}$-(4-(benzyloxy)phenyl)-6,7-dimethoxyquinolin-4-amine (49) was obtained as a beige solid (187 mg, $0.483 \mathrm{mmol}, 72 \%$ ). MP $>250{ }^{\circ} \mathrm{C} ;{ }^{1} \mathrm{H}$ NMR $\left(400 \mathrm{MHz},\left[\mathrm{D}_{6}\right] \mathrm{DMSO}\right) \delta 10.68(\mathrm{~s}, 1 \mathrm{H}), 8.28(\mathrm{~d}$, $J=7.0 \mathrm{~Hz}, 1 \mathrm{H}), 8.18(\mathrm{~s}, 1 \mathrm{H}), 7.78-7.23(\mathrm{~m}, 8 \mathrm{H}), 7.23-7.12(\mathrm{~m}$ 2H), $6.55(\mathrm{~d}, J=7.0 \mathrm{~Hz}, 1 \mathrm{H}), 5.17(\mathrm{~s}, 2 \mathrm{H}), 3.99(\mathrm{~s}, 3 \mathrm{H}), 3.95(\mathrm{~s}$ 3H). ${ }^{13} \mathrm{C}$ NMR (101 MHz, [D $]$ DMSO) $\delta 157.2,154.4,153.6,149.3$ 139.6, 136.8, 135.2, 130.2, 128.5 (2C, s), 127.9, 127.8 (2C, s), $127.2,115.9,111.3,102.8,99.8,98.7,69.6,56.7,56.1$. calcd for $\mathrm{C}_{24} \mathrm{H}_{23} \mathrm{~N}_{2} \mathrm{O}_{3}{ }^{+} 387.1703$, found 387.1707 ; LC: $\mathrm{t}_{\mathrm{R}}=4.89$ min, purity $>98 \%$. 
bioRxiv preprint doi: https://doi.org/10.1101/2020.03.02.972943; this version posted March 3, 2020. The copyright holder for this preprint (which was not certified by peer review) is the author/funder, who has granted bioRxiv a license to display the preprint in perpetuity. It is made available under aCC-BY-NC 4.0 International license.

N-(4-(benzyloxy)phenyl)-6-bromoquinolin-4-amine (50) was obtained as a yellow solid (183 mg, $0.452 \mathrm{mmol}, 73 \%$ ). MP 129$131{ }^{\circ} \mathrm{C} ;{ }^{1} \mathrm{H}$ NMR $\left(400 \mathrm{MHz},\left[\mathrm{D}_{6}\right] \mathrm{DMSO}\right) \delta 10.96(\mathrm{~s}, 1 \mathrm{H}), 9.11(\mathrm{~d}$, $J=2.1 \mathrm{~Hz}, 1 \mathrm{H}), 8.48(\mathrm{~d}, J=7.0 \mathrm{~Hz}, 1 \mathrm{H}), 8.16(\mathrm{dd}, J=9.0,2.0 \mathrm{~Hz}$, $1 \mathrm{H}), 8.04(\mathrm{~d}, J=9.0 \mathrm{~Hz}, 1 \mathrm{H}), 7.72-7.25(\mathrm{~m}, 7 \mathrm{H}), 7.25-7.16(\mathrm{~m}$, $2 \mathrm{H}), 6.69(\mathrm{~d}, J=7.0 \mathrm{~Hz}, 1 \mathrm{H}), 5.18(\mathrm{~s}, 2 \mathrm{H}) .{ }^{13} \mathrm{C}$ NMR $(101 \mathrm{MHz}$, $\left.\left[\mathrm{D}_{6}\right] \mathrm{DMSO}\right) \delta 157.5,154.4,142.9,137.3,136.8,136.5,129.6$, 128.5 (2C, s), 128.0, 127.8 (2C, s), 127.0, 126.1, 122.5, 119.7, 118.4, 116.0, 100.1, 69.6. calcd for $\mathrm{C}_{22} \mathrm{H}_{18} \mathrm{BrN}_{2} \mathrm{O}^{+}$405.0597, found 405.0603 ; LC: $t_{R}=5.03$ min, purity $>98 \%$.

$N$-(4-(Benzyloxy)phenyl)-5,7-difluoroquinolin-4-amine (51): was obtained as a mustard solid (130 mg, $0.359 \mathrm{mmol}, 58 \%$ ); m.p. $231^{\circ} \mathrm{C} ;{ }^{1} \mathrm{H}$ NMR $\left(400 \mathrm{MHz},\left[\mathrm{D}_{6}\right] \mathrm{DMSO}\right) \delta 10.22$ (d, $J=12.0$ $\mathrm{Hz}, 1 \mathrm{H}), 8.43(\mathrm{~d}, J=7.1 \mathrm{~Hz}, 1 \mathrm{H}), 7.84-7.73(\mathrm{~m}, 2 \mathrm{H}), 7.52-7.46$ $(\mathrm{m}, 2 \mathrm{H}), 7.45-7.32(\mathrm{~m}, 5 \mathrm{H}), 7.25-7.18(\mathrm{~m}, 2 \mathrm{H}), 6.50(\mathrm{~d}, J=7.1$ $\mathrm{Hz}, 1 \mathrm{H}), 5.18 \mathrm{ppm}(\mathrm{s}, 2 \mathrm{H}) ;{ }^{13} \mathrm{C}$ NMR $\left(101 \mathrm{MHz},\left[\mathrm{D}_{6}\right.\right.$ ]DMSO) $\delta$ 163.63 (dd, $J=253.6,15.3 \mathrm{~Hz}$ ), 160.25 (dd, $J=258.0,15.2 \mathrm{~Hz}$ ), $157.88,154.82$ (d, $J=2.9 \mathrm{~Hz}), 143.11,140.91$ (dd, $J=15.0,6.4$ $\mathrm{Hz}), 136.75$, 129.82, 128.49, 127.96, 127.93, 127.77, 116.05, 105.22 (dd, $J=13.1,2.1 \mathrm{~Hz}), 103.74-102.64(\mathrm{~m}), 101.66(\mathrm{dd}, J$ $=25.1,4.2 \mathrm{~Hz}), 100.99,69.53 \mathrm{ppm}$; HRMS-ESI $(\mathrm{m} / \mathrm{z}):[\mathrm{M}+\mathrm{H}]^{+}$ calcd for $\mathrm{C}_{22} \mathrm{H}_{17} \mathrm{~F}_{2} \mathrm{~N}_{2} \mathrm{O}^{+}$363.1303, found 363.1298; LC: $t_{R}=4.32$ min, purity $>98 \%$.

$\mathrm{N}$-(4-((3-fluorobenzyl)oxy)phenyl)-6,7-dimethoxyquinolin-4amine (52) was obtained as a dark green solid (130 mg, 0.321 mmol, 48\%). MP decomp. $220^{\circ} \mathrm{C} ;{ }^{1} \mathrm{H}$ NMR $(400 \mathrm{MHz}$, [D, DMSO) $\delta 10.65(\mathrm{~s}, 1 \mathrm{H}), 8.29(\mathrm{~d}, J=6.9 \mathrm{~Hz}, 1 \mathrm{H}), 8.17(\mathrm{~s}, 1 \mathrm{H}), 7.50-7.43$ $(\mathrm{m}, 2 \mathrm{H}), 7.42-7.36(\mathrm{~m}, 2 \mathrm{H}), 7.35-7.28(\mathrm{~m}, 2 \mathrm{H}), 7.22-7.10(\mathrm{~m}$, $3 \mathrm{H}), 6.55(\mathrm{~d}, J=6.9 \mathrm{~Hz}, 1 \mathrm{H}), 5.20(\mathrm{~s}, 2 \mathrm{H}), 3.99(\mathrm{~s}, 3 \mathrm{H}), 3.95(\mathrm{~s}$, $3 \mathrm{H}) .{ }^{13} \mathrm{C}$ NMR (101 MHz, [D $]$ DMSO) $\delta 162.2(\mathrm{~d}, J=243.7 \mathrm{~Hz})$, $156.9,154.4,153.5,149.3,139.8,139.8(d, J=1.6 \mathrm{~Hz}), 135.3$, $130.5(\mathrm{~d}, J=8.3 \mathrm{~Hz}), 130.4,127.2,123.6(\mathrm{~d}, J=2.7 \mathrm{~Hz}), 115.9$, $114.7(\mathrm{~d}, J=20.9 \mathrm{~Hz}), 114.3(\mathrm{~d}, J=21.8 \mathrm{~Hz}), 111.4,102.7,100.0$, 98.8, $68.7(\mathrm{~d}, J=2.1 \mathrm{~Hz}), 56.7,56.1 \mathrm{ppm}$; HRMS-ESI $(\mathrm{m} / \mathrm{z})$ : $[\mathrm{M}+\mathrm{H}]^{+}$calcd for $\mathrm{C}_{24} \mathrm{H}_{22} \mathrm{FN}_{2} \mathrm{O}_{3}+405.1609$, found 405.0617 , ; LC: $\mathrm{t}_{\mathrm{R}}=4.46 \mathrm{~min}$, purity $>98 \%$

\section{6-bromo-N-(4-((3-fluorobenzyl)oxy)phenyl)quinolin-4-amine}

(53) was obtained as a dark green solid $(144 \mathrm{mg}, 0.340 \mathrm{mmol}$, $55 \%)$. MP $111-113^{\circ} \mathrm{C} ;{ }^{1} \mathrm{H} \mathrm{NMR}\left(400 \mathrm{MHz},\left[\mathrm{D}_{6}\right] \mathrm{DMSO}\right) \delta 11.01$ (s, $1 \mathrm{H}), 9.13(\mathrm{~d}, J=2.0 \mathrm{~Hz}, 1 \mathrm{H}), 8.48(\mathrm{~d}, J=7.0 \mathrm{~Hz}, 1 \mathrm{H}), 8.15(\mathrm{dd}, J$ $=9.0,2.0 \mathrm{~Hz}, 1 \mathrm{H}), 8.06(\mathrm{~d}, J=9.0 \mathrm{~Hz}, 1 \mathrm{H}), 7.47(\mathrm{td}, J=8.1,6.0$ $\mathrm{Hz}, 1 \mathrm{H}), 7.43-7.37(\mathrm{~m}, 2 \mathrm{H}), 7.36-7.28(\mathrm{~m}, 2 \mathrm{H}), 7.24-7.19(\mathrm{~m}$, 2H), 7.17 (ddd, $J=8.2,3.1,1.1 \mathrm{~Hz}, 1 \mathrm{H}), 6.69(\mathrm{~d}, J=7.0 \mathrm{~Hz}, 1 \mathrm{H})$, $5.21(\mathrm{~s}, 2 \mathrm{H}) \cdot{ }^{13} \mathrm{C}$ NMR $\left(101 \mathrm{MHz},\left[\mathrm{D}_{6}\right] \mathrm{DMSO}\right) \delta 162.2(\mathrm{~d}, J=243.5$ $\mathrm{Hz}$ ), 157.3, 154.4, 142.8, 139.7 (d, $J=7.3 \mathrm{~Hz}$ ), 137.3, 136.5, $130.5(\mathrm{~d}, J=8.3 \mathrm{~Hz}), 129.8,127.0(2 \mathrm{C}, \mathrm{s}), 126.1,123.6(\mathrm{~d}, J=$ $2.7 \mathrm{~Hz}), 122.4,119.7,118.4,116.0(2 \mathrm{C}, \mathrm{s}), 114.7(\mathrm{~d}, J=20.9 \mathrm{~Hz})$, $114.3(\mathrm{~d}, J=21.9 \mathrm{~Hz}), 100.1,68.7 \mathrm{ppm}(\mathrm{d}, J=1.9 \mathrm{~Hz})$; HRMSESI $(\mathrm{m} / \mathrm{z}):[\mathrm{M}+\mathrm{H}]^{+}$calcd for $\mathrm{C}_{22} \mathrm{H}_{17} \mathrm{BrFN}_{2} \mathrm{O}^{+} 423.0503$, found 423.0512; LC: $t_{R}=5.11 \mathrm{~min}$, purity $>98 \%$.

$\mathbf{N}$-(4-((4-fluorobenzyl)oxy)phenyl)-6,7-dimethoxyquinolin-4amine (54) was obtained as a grey solid $(176 \mathrm{mg}, 0.426 \mathrm{mmol}$, $65 \%$ ). MP decomp. $210{ }^{\circ} \mathrm{C} ;{ }^{1} \mathrm{H}$ NMR $\left(400 \mathrm{MHz},\left[\mathrm{D}_{6}\right] \mathrm{DMSO}\right) \delta$ $10.71(\mathrm{~s}, 1 \mathrm{H}), 8.27(\mathrm{~d}, J=7.0 \mathrm{~Hz}, 1 \mathrm{H}), 8.19(\mathrm{~s}, 1 \mathrm{H}), 7.57-7.49$ $(\mathrm{m}, 2 \mathrm{H}), 7.47(\mathrm{~s}, 1 \mathrm{H}), 7.42-7.35(\mathrm{~m}, 2 \mathrm{H}), 7.28-7.20(\mathrm{~m}, 2 \mathrm{H})$, $7.20-7.13(\mathrm{~m}, 2 \mathrm{H}), 6.54(\mathrm{~d}, J=6.9 \mathrm{~Hz}, 1 \mathrm{H}), 5.14(\mathrm{~s}, 2 \mathrm{H}), 3.99$ (s, 3H), $3.94(\mathrm{~s}, 3 \mathrm{H}) .{ }^{13} \mathrm{C} \mathrm{NMR}\left(101 \mathrm{MHz},\left[\mathrm{D}_{6}\right] \mathrm{DMSO}\right) \delta 161.8(\mathrm{~d}$, $J=243.8 \mathrm{~Hz}), 157.0,154.4,153.5,149.2,139.6,135.3,133.1(\mathrm{~d}$, $J=3.0 \mathrm{~Hz}$ ), 130.3, 130.0 (d, $J=8.3 \mathrm{~Hz}, 2 \mathrm{C}$ ), 127.2 (s, 2C), 115.9 (s, 2C), 115.3 (d, J=21.4 Hz, 2C), 111.4, 102.8, 99.9, 98.7, 68.8, 56.8, 56.1. HRMS-ESI $(\mathrm{m} / \mathrm{z}):[\mathrm{M}+\mathrm{H}]^{+}$calcd for $\mathrm{C}_{24} \mathrm{H}_{22} \mathrm{FN}_{2} \mathrm{O}_{3}{ }^{+}$ 405.1609 , found 405.1613 ; $L C: t_{R}=4.91 \mathrm{~min}$, purity $>98 \%$.

6-bromo- $N$ - $\{4-[(4-f l u o r o p h e n y l) m e t h o x y] p h e n y l\} q u i n o l i n-4-$ amine (55) was obtained as a dark yellow solid (178 $\mathrm{mg}, 0.421$ mmol, 68\%). MP 128-120 ${ }^{\circ} \mathrm{C} ;{ }^{1} \mathrm{H}$ NMR $\left(400 \mathrm{MHz},\left[\mathrm{D}_{6}\right] \mathrm{DMSO}\right) \delta$ 10.95 (s, 1H), 9.11 (d, $J=2.0 \mathrm{~Hz}, 1 \mathrm{H}), 8.48(\mathrm{~d}, J=7.0 \mathrm{~Hz}, 1 \mathrm{H})$, $8.15(\mathrm{dd}, J=9.0,2.0 \mathrm{~Hz}, 1 \mathrm{H}), 8.04(\mathrm{~d}, J=9.0 \mathrm{~Hz}, 1 \mathrm{H}), 7.71-7.47$ $(\mathrm{m}, 2 \mathrm{H}), 7.47-7.32(\mathrm{~m}, 2 \mathrm{H}), 7.32-7.00(\mathrm{~m}, 4 \mathrm{H}), 6.69(\mathrm{~d}, J=6.9$ $\mathrm{Hz}, 1 \mathrm{H}), 5.16(\mathrm{~s}, 2 \mathrm{H}) .{ }^{13} \mathrm{C}$ NMR (101 MHz, [D 6 DMSO) $\delta 161.8$ (d, $J=243.5 \mathrm{~Hz}), 157.4,154.3,143.0,137.4,136.4,133.0(\mathrm{~d}, J=3.0$ $\mathrm{Hz}), 130.1$ (d, $J=8.2 \mathrm{~Hz}, 2 \mathrm{C}), 129.7,127.0$ (s, 2C), 126.1, 122.6, 119.7, 118.4, 116.0 (s, 2C), 115.3 (d, $J=21.4 \mathrm{~Hz}, 2 \mathrm{C}$ ), 100.1 68.8 ppm; HRMS-ESI $(\mathrm{m} / \mathrm{z})$ : $[\mathrm{M}+\mathrm{H}]^{+}$calcd for $\mathrm{C}_{22} \mathrm{H}_{17} \mathrm{BrFN}_{2} \mathrm{O}^{+}$ 423.0503, found 423.0511; LC: $t_{R}=5.09$ min, purity $>98 \%$.

N-(4-((2-fluorobenzyl)oxy)phenyl)-6,7-dimethoxyquinolin-4amine (56) was obtained as a grey solid $(94 \mathrm{mg}, 0.235 \mathrm{mmol}$, $35 \%)$. MP 232-234 ${ }^{\circ} \mathrm{C} ;{ }^{1} \mathrm{H}$ NMR $\left(400 \mathrm{MHz},\left[\mathrm{D}_{6}\right.\right.$ ]DMSO) $\delta 10.56$ (s, $1 \mathrm{H}), 8.29(\mathrm{~d}, J=6.9 \mathrm{~Hz}, 1 \mathrm{H}), 8.14(\mathrm{~s}, 1 \mathrm{H}), 7.60(\mathrm{td}, J=7.6,1.7$ $\mathrm{Hz}, 1 \mathrm{H}), 7.56-7.42(\mathrm{~m}, 2 \mathrm{H}), 7.42-7.32(\mathrm{~m}, 2 \mathrm{H}), 7.32-7.23(\mathrm{~m}$, $2 \mathrm{H}), 7.23-7.07(\mathrm{~m}, 2 \mathrm{H}), 6.57(\mathrm{~d}, J=6.9 \mathrm{~Hz}, 1 \mathrm{H}), 5.20(\mathrm{~s}, 2 \mathrm{H})$, 3.99 (s, 3H), $3.96(\mathrm{~s}, 3 \mathrm{H}) \cdot{ }^{13} \mathrm{C}$ NMR $\left(101 \mathrm{MHz},\left[\mathrm{D}_{6}\right] \mathrm{DMSO}\right) \delta 160.5$ $(\mathrm{d}, J=246.2 \mathrm{~Hz}), 157.0,154.4,153.4,149.3,140.0,135.6,130.8$ (d, $J=4.1 \mathrm{~Hz}), 130.6,130.5,127.2(2 \mathrm{C}, \mathrm{s}), 124.6(\mathrm{~d}, J=3.5 \mathrm{~Hz})$, $123.6(\mathrm{~d}, J=14.5 \mathrm{~Hz}), 115.9(2 \mathrm{C}, \mathrm{s}), 115.4(\mathrm{~d}, J=21.0 \mathrm{~Hz}), 111.4$, 102.6, 100.2, 98.8, 63.9 (d, $J=3.6 \mathrm{~Hz}), 56.7,56.1 \mathrm{ppm}$; HRMSESI (m/z): $[\mathrm{M}+\mathrm{H}]^{+}$calcd for $\mathrm{C}_{24} \mathrm{H}_{22} \mathrm{FN}_{2} \mathrm{O}_{3}{ }^{+} 405.1609$, found 405.1612; LC: $\mathrm{t}_{\mathrm{R}}=4.90 \mathrm{~min}$, purity $>98 \%$.

6-bromo-N-(4-((2-fluorobenzyl)oxy)phenyl)quinolin-4-amine (57) was obtained as a green solid (113 $\mathrm{mg}, 0.266 \mathrm{mmol}, 43 \%)$ MP $126-128{ }^{\circ} \mathrm{C} ;{ }^{1} \mathrm{H}$ NMR $\left(400 \mathrm{MHz},\left[\mathrm{D}_{6}\right] \mathrm{DMSO}\right) \delta 10.89(\mathrm{~s}, 1 \mathrm{H})$, $9.08(\mathrm{~d}, J=2.1 \mathrm{~Hz}, 1 \mathrm{H}), 8.49(\mathrm{~d}, J=7.0 \mathrm{~Hz}, 1 \mathrm{H}), 8.16(\mathrm{dd}, J=$ 9.0, $2.0 \mathrm{~Hz}, 1 \mathrm{H}), 8.02(\mathrm{~d}, J=9.0 \mathrm{~Hz}, 1 \mathrm{H}), 7.60(\mathrm{td}, J=7.5,1.7 \mathrm{~Hz}$, $1 \mathrm{H}), 7.49-7.22(\mathrm{~m}, 6 \mathrm{H}), 6.71(\mathrm{~d}, J=7.0 \mathrm{~Hz}, 1 \mathrm{H}), 5.21(\mathrm{~s}, 2 \mathrm{H})$ ${ }^{13} \mathrm{C}$ NMR $\left(101 \mathrm{MHz},\left[\mathrm{D}_{6}\right] \mathrm{DMSO}\right) \delta 160.5(\mathrm{~d}, J=246.2 \mathrm{~Hz}), 157.4$, 154.3, 143.1, 137.4, 136.5, 130.9 (d, $J=4.0 \mathrm{~Hz}), 130.6$ (d, $J=8.3$ $\mathrm{Hz}), 129.9,127.0$ (2C, s), 126.0, 124.6 (d, J = 3.4 Hz), 123.5 (d, J $=14.5 \mathrm{~Hz}), 122.6,119.7,118.4,116.0(2 \mathrm{C}, \mathrm{s}), 115.5(\mathrm{~d}, J=20.9$ $\mathrm{Hz}), 100.2,64.0 \mathrm{ppm}(\mathrm{d}, J=3.6 \mathrm{~Hz})$; HRMS-ESI $(\mathrm{m} / \mathrm{z}):[\mathrm{M}+\mathrm{H}]^{+}$ calcd for $\mathrm{C}_{22} \mathrm{H}_{17} \mathrm{BrFN}_{2} \mathrm{O}^{+}$423.0503, found 423.0512; LC: $t_{R}=5.07$ Min, purity $>98 \%$

\section{Acknowledgements}

The SGC is a registered charity (number 1097737) that receives funds from AbbVie, Bayer Pharma AG, Boehringer Ingelheim, Canada Foundation for Innovation, Eshelman Institute for Innovation, Genome Canada, Innovative Medicines Initiative (EU/EFPIA) [ULTRA-DD grant no. 115766], Janssen, Merck KGaA Darmstadt Germany, MSD, Novartis Pharma AG, Ontario Ministry of Economic Development and Innovation, Pfizer, São Paulo Research Foundation-FAPESP, Takeda, and Wellcome [106169/ZZ14/Z]. Research reported in this publication was also supported by a grant from the National Center for Advancing Translational Sciences (NCATS) of the National Institute of Health "Tools for Accelerating R\&D for Historically Understudied Protein Kinases" (1R44TR001916-01) and by the National Institute of Health "Illuminating the Druggable Genome program" (grant number 1U24DK116204-01). The content is solely the responsibility of the authors and does not necessarily represent the official views of the National Institute of Health. In addition, we thank Biocenter Finland/DDCB for financial support and CSC - IT Center for Science Ltd. Finland for the use of their facilities, software licenses and computational resources. We are grateful Dr. Brandie Ehrmann and Diane Wallace for LC-MS/HRMS support provided by the Mass Spectrometry Core Laboratory at the University of North Carolina at Chapel Hill. We also thank the EPSRC UK National Crystallography Service for funding and collection of the crystallographic data for $\mathbf{5 2 , 5 4}$ and 57 .

Keywords: Protein Kinase Novel 3 (PKN3) • 4-anilinoquinoline • 4-anilinoquinazoline $\cdot$ Homology Model $•$

\section{References}


bioRxiv preprint doi: https://doi.org/10.1101/2020.03.02.972943; this version posted March 3, 2020. The copyright holder for this preprint (which was not certified by peer review) is the author/funder, who has granted bioRxiv a license to display the preprint in perpetuity. It is made available under aCC-BY-NC 4.0 International license.

[1] K. Shiga, K. Takayama, S. Futaki, J. E. Hutti, L. C. Cantley, K. Ueki, Y. Ono, H. Mukai, Biochem J. 2009, 425, 445-453.

[2] M. D. Falk, W. Liu, B. Bolaños, K. Unsal-Kacmaz, A. Klippel, S. Grant, A. Brooun, S. Timofeevski 2014, 34, 92-106.

[3] C. L. Hutchinson, P. N. Lowe, S. H. McLaughlin, H. R. Mott, D. Owen 2013, 52, 7999-8011.

[4] H. Mukai, J. Biochem. 2003, 133, 17-27.

[5] F. Leenders, K. Möpert, A. Schmiedeknecht, A. Santel, F. Czauderna, M. Aleku, S. Penschuck, S. Dames, M. Sternberger, T. Röhl, A. Wellmann, W. Arnold, K. Giese, J. Kaufmann, A. Klippel, EMBO J. 2004, 23, 3303-3313.

[6] B. Thauerer, S. Zur Nedden, G. Baier-Bitterlich, Curr. Neuropharmacol. 2014, 12, 213-218.

[7] H. Mukai, A. Muramatsu, R. Mashud, K. Kubouchi, S. Tsujimoto, T. Hongu, Y. Kanaho, M. Tsubaki, S. Nishida, G. Shioi, S. Danno, M. Mehruba, R. Satoh, R. Sugiura, Sci. Rep. 2016, 6, 18979.

[8] K. Unsal-Kacmaz, S. Ragunathan, E. Rosfjord, S. Dann, E. Upeslacis, M. Grillo, R. Hernandez, F. Mack, A. Klippel, Mol. Oncol. 2012, 6, 284-298.

[9] J. Gemperle, M. Dibus, L. Koudelková, D. Rosel, J. Brábek, Mol. Oncol. 2019, 13, 264-289.

[10] M. Kraus, B. Dolinski, T. W. Rosahl, J. A. Magee, Leukemia 2015, 29, 255-258.

[11] A. Santel, M. Aleku, N. Röder, K. Möpert, B. Durieux, O. Janke, O. Keil, J. Endruschat, S. Dames, C. Lange, M. Eisermann, K. Löffler, M. Fechtner, G. Fisch, C. Vank, U. Schaeper, K. Giese, J. Kaufmann, Clin. Cancer Res. 2010, 16, 5469-5480.

[12] B. Schultheis, D. Strumberg, A. Santel, C. Vank, F. Gebhardt, O. Keil, C. Lange, K. Giese, J. Kaufmann, M. Khan, J. Drevs, J. Clin. Oncol. 2014, 32, 4141-4148.

[13] L. Aagaard, J. J. Rossi, Adv. Drug Delivery Rev. 2007, 59, 7586.

[14] M. Aleku, P. Schulz, O. Keil, A. Santel, U. Schaeper, B. Dieckhoff, O. Janke, J. Endruschat, B. Durieux, N. Röder, K. Löffler, C. Lange, M. Fechtner, K. Möpert, G. Fisch, S. Dames, W. Arnold, K. Jochims, K. Giese, B. Wiedenmann, A. Scholz, J. Kaufmann 2008, 68, 9788-9798.

[15] R. Titze-de-Almeida, C. David, S. S. Titze-de-Almeida, Pharm. Res. 2017, 34, 1339-1363.

[16] A. Gutierrez, T. Sanda, R. Grebliunaite, A. Carracedo, L. Salmena, Y. Ahn, S. Dahlberg, D. Neuberg, L. A. Moreau, S. S. Winter, R. Larson, J. Zhang, A. Protopopov, L. Chin, P. P. Pandolfi, L. B. Silverman, S. P. Hunger, S. E. Sallan, A. T. Look 2009, 114, 647-650.

[17] M. R. Janes, J. J. Limon, L. So, J. Chen, R. J. Lim, M. A. Chavez, C. Vu, M. B. Lilly, S. Mallya, S. T. Ong, M. Konopleva, M. B. Martin, P. Ren, Y. Liu, C. Rommel, D. A. Fruman, Nat. Med. (N. Y., NY, U. S.) 2010, 16, 205-213.

[18] A. M. Martelli, M. Nyåkern, G. Tabellini, R. Bortul, P. L. Tazzari, C. Evangelisti, L. Cocco, Leukemia 2006, 20, 911928.

[19] S. Uehara, N. Udagawa, H. Mukai, A. Ishihara, K. Maeda, T. Yamashita, K. Murakami, M. Nishita, T. Nakamura, S. Kato, Y. Minami, N. Takahashi, Y. Kobayashi, Sci. Signaling 2017, 10.

[20] C. H. Arrowsmith, J.E. Audia, C. Austin, J. Baell, J. Bennett, J. Blagg, C. Bountra, P. E. Brennan, P. J. Brown, M. E. Bunnage, C. Buser-Doepner, R. M. Campbell, A. J. Carter, P. Cohen, R. A. Copeland, B. Cravatt, J. L. Dahlin, D. Dhanak, A. M. Edwards M. Frederiksen, S. V. Frye, N. Gray, C. E. Grimshaw, D. Hepworth, T. Howe, K. V. Huber, J. Jin, S. Knapp, J .D. Kotz, R. G. Kruger, D. Lowe, M. M. Mader, B. Marsden, A. MuellerFahrnow, S. Müller, R. C. O'Hagen, J. P. Overington, D. R. Owen, S. H. Rosen-berg, B. Roth, R. Ross, M. Schapira, S. L. Schreiber, B. Shoicet, M. Sundström, G. Superti-Furga, J. Taunton, L. Toledo-Sherman, C. Walpole, M. A. Walters, T. M. Wilson, P. Workman, R. N. Young, W. J. Zuercher, Nat. Chem. Biol. 2015, 11, 536-542.

[21] C. M. Browne, B. Jiang, S. B. Ficarro, Z. M. Doctor, J. L. Johnson, J. D. Card, S. C. Sivakumaren, W. M. Alexander, T.
M. Yaron, C. J. Murphy, N. P. Kwiatkowski, T. Zhang, L. C Cantley, N. S. Gray, J. A. Marto J Am Chem Soc. 2019, 141, 191-203.

[22] M. A. Fabian, W. H. Biggs III, D. K. Treiber, C. E. Atteridge, M D. Azimioara, M. G. Benedetti, T. A. Carter, P. Ciceri, P. T. Edeen, M. Floyd, J. M. Ford, M. Galvin, J. L. Gerlach, R. M. Grotzfeld, S. Herrgard, D. E. Insko, M. A. Insko, A. G. Lai, J. M. Lelias, S. A. Mehta, Z. V. Milanov, A. M. Velasco, L. M. Wodicka, H. K. Patel, P. P. Zarrinkar, D. J. Lockhart, Nat Biotechnol. 2005, 23, 329-336

[23] M. I. Davis, J. P. Hunt, S. Herrgard, P. Ciceri, L. M. Wodicka, G Pallares, M. Hocker, D. K. Treiber, P. P. Zarrinkar, Nat Biotechnol. 2011, 29, 1046-1051.

[24] T. Anastassiadis, S. W. Deacon, K. Devarajan, H. Ma, J. R. Peterson Nat Biotechnol. 2011, 29, 1039-1045.

[25] J. M. Elkins, V. Fedele, M. Szklarz, K. R. A. Azeez, E. Salah, J. Mikolajczyk, S. Romanov, N. Sepetov, X. Huang, B. L. Roth, A A. H. Zen, D. Fourches, E. Muratov, A. Tropsha, J. Morris, B. A Teicher, M. Kunkel, E. Polley, K. E. Lackey, F. L. Atkinson, J. P. Overington, P. Bamborough, S. Müller, D. J. Price, T. M. Willson, D. H. Drewry, S. Knapp, W. J. Zuercher, Nat Biotechnol. 2016 , 34, 95-103.

[26] D. H. Drewry, C. I. Wells, D. M. Andrews, R. Angell, H. Al-Ali, A D. Axtman, S. J. Capuzzi, J. M. Elkins, P. Ettmayer, M. Frederiksen, O. Gileadi, N. Gray, A. Hooper, S. Knapp, S. Laufer, U. Luecking, M. Michaelides, S. Müller, E. Muratov, R. A. Denny, K. S. Saikatendu, D. K. Treiber, W. J. Zuercher, T. M. Willson, PLoS One. 2017, 12, e0181585.

[27] O. Fedorov, S. Müller, S. Knapp, Nat. Chem. Biol. 2010, 6, 166169.

[28] S. Knapp, P. Arruda, J. Blagg, S. Burley, D. H. Drewry, A Edwards, D. Fabbro, P. Gillespie, N. S. Gray, B. Kuster, K. E. Lackey, P. Mazzafera, N. C. O. Tomkinson, T. M. Willson, P. Workman, W. J. Zuercher Nat. Chem. Biol. 2013, 9, 3-6.

[29] B. W. Jester, K. J. Cox, A. Gaj, C. D. Shomin, J. R. Porter, I. Ghosh, J. Am. Chem Soc. 2010, 132, 11727-11735.

[30] B. W. Jester, A. Gaj, C. D. Shomin, K. J. Cox, I. Ghosh, J. Med. Chem. 2012, 55, 1526-1537.

[31] Q. Deng, D. Wang, X. Xiang, X. Gao, P. R. Hardwidge, R. S. Kaushik, T. Wolff, S. Chakravarty, F. Li J Virol Methods. 2011, 176, 108-111.

[32] C. R. M. Asquith, T. Laitinen, J. M. Bennett, P. H. Godoi, M. P. East, G. J. Tizzard, L. M. Graves, G. L. Johnson, R. E. Dornsife, C. I. Wells, J. M. Elkins, T. M. Willson, W. J. Zuercher, ChemMedChem 2018, 13, 48-66.

[33] C. R. M. Asquith, B. T. Berger, J. Wan, J. M. Bennett, S. J. Capuzzi, D. J. Crona, D. H. Drewry, M. P. East, J. M. Elkins, O. Fedorov, P. H. Godoi, D. M. Hunter, S. Knapp, S. Müller, C. D. Torrice, C. I. Wells, H. S. Earp, T. M. Willson, W. J. Zuercher, J. Med. Chem. 2019, 62, 2830-2836.

[34] C. R. M. Asquith, K. M. Naegeli, M. P. East, T. Laitinen, T. M Havener, C. I. Wells, G. L. Johnson, D. H. Drewry, W. J. Zuercher, D. C. Morris, J Med Chem. 2019, 62, 4772-4778.

[35] C. R. M. Asquith, D. K. Treiber, W. J. Zuercher, Bioorg. Med. Chem. Lett. 2019, 29, 1727-1731.

[36] C. R. M. Asquith, J. M. Bennett, L. Su, T. Laitinen, J. M. Elkins, J. E. Pickett, C. I. Wells, Z. Li, T. M. Willson, W. J. Zuercher, Molecules. 2019, 24, pii: E4016.

[37] C. R. M. Asquith, T. Laitinen, J. M. Bennett, C. I. Wells, J. M. Elkins, W. J. Zuercher, G. J. Tizzard, A. Poso, ChemMedChem. 2020, 15, 26-49.

[38] C. R. M. Asquith, K. A. Maffuid, T. Laitinen, C. D. Torrice, G. J. Tizzard, D. J. Crona, W. J. Zuercher, ChemMedChem. 2019 14, 1693-1700.

[39] T. Machleidt, C. C. Woodroofe, M. K. Schwinn, J. Méndez, M. B. Robers, K. Zimmerman, P. Otto, D. L. Daniels, T. A. Kirkland, K. V. Wood, ACS Chem. Biol. 2015, 10, 1797-1804.

[40] J. D. Vasta, C. R. Corona, J. Wilkinson, C. A. Zimprich, J. R. Hartnett, M. R. Ingold, K. Zimmerman, T. Machleidt, T. A. Kirkland, K. G. Huwiler, R. F. Ohana, M. Slater, P. Otto, M. Cong, C. I. Wells, B.-T. Berger, T. Hanke, C. Glas, K. Ding, D. H. Drewry, K. V. M. Huber, T. M. Willson, S. Knapp, S. Müller, P. L. Meisenheimer, F. Fan, K. V. Wood, M. B. Robers, Cell Chem. Biol. 2018, 25, 206-214. 
bioRxiv preprint doi: https://doi.org/10.1101/2020.03.02.972943; this version posted March 3, 2020. The copyright holder for this preprint (which was not certified by peer review) is the author/funder, who has granted bioRxiv a license to display the preprint in perpetuity. It is made available under aCC-BY-NC 4.0 International license.

[41] D. Kitagawa, K. Yokota, M. Gouda, Y. Narumi, H. Ohmoto, E. Nishiwaki, K. Akita, Y. Kirii, Genes Cells. 2013, 18, 110-122.

[42] A. F. A. Keszei, X. Tang, C. McCormick, E. Zeqiraj, J. R. Rohde, M. Tyers, F. Sicheri, Mol Cell Biol 2014, 34, 362-373.

[43] P. Chamberlain, S. Delker, B. Pagarigan, A. Mahmoudi, P. Jackson, M. Abbasian, J. Muir, N. Raheja, B. Cathers, PLoS One 2014, 9, e103638

[44] G. M. Sheldrick, Acta Crystallogr. Sect. A 2015, 71, 3-8.

[45] L. Palatinus, G. Chapuis, J. Appl. Crystallogr. 2007, 40, 786790.

[46] G. M. Sheldrick, Acta Crystallogr. Sect. C 2015, 71, 3-8.

[47] a) F. M. Ferguson, N. S. Gray, Nat Rev Drug Discov. 2018, 17, 353-377; b) http://www.brimr.org/PKI/PKIs.htm

[48] P. Cohen, D. R. Alessi, ACS Chem. Biol. 2013, 8, 96-104.

[49] A. F. Rudolf, T. Skovgaard, S. Knapp, L. J. Jensen, J. Berthelsen, PLoS One 2014, 9, e98800.

[50] H. Ma, S. Deacon, K. Horiuchi, Expert Opin. Drug Discovery 2008, 3, 607-621.

[51] A. F. Rudolf, T. Skovgaard, S. Knapp, L. J. Jensen, J. A. Berthelsen, PLoS One 2014, 9, e98800.

[52] H. Ma, S. Deacon, K. Horiuchi, Expert Opin. Drug Discovery 2008, 3, 607-621.

[53] J. A. Endicott, M. E. Noble, L. N. Johnson Annu Rev Biochem. 2012, 81, 587-613.

[54] a) N. Ohbayashi, K. Murayama, M. Kato-Murayama, M. Kukimoto-Niino, T. Uejima, T. Matsuda, N. Ohsawa, S. Yokoyoma, H. Nojima, M. Shirouzu, ChemistryOpen. 2018, 7, 721-727. B) Schrödinger Maestro software package (SmallMolecule Drug Discovery Suite 2018-4, Schrödinger, LLC, New York, NY, 2018).

[55] C. R. M. Asquith, N. Fleck, C. D. Torrice, D. J. Crona, C. Grundner, W. J. Zuercher, Bioorg. Med. Chem. Lett. 2019, 18 2695-2699.

[56] B. W. Jester, K. J. Cox, A. Gaj, C. D. Shomin, J. R. Porter, I. Ghosh, J. Am. Chem. Soc. 2010, 132, 11727-11735. 
bioRxiv preprint doi: https://doi.org/10.1101/2020.03 02.972943. this version posted March 3, 2020. The copyright holder for this preprint (which was not certified by peer review) is the author/funder, who has granted bioRxiv a license to display the preprint in perpetuity. It is made available under aCC-BY-NC 4.0 International license.

\section{Graphic}

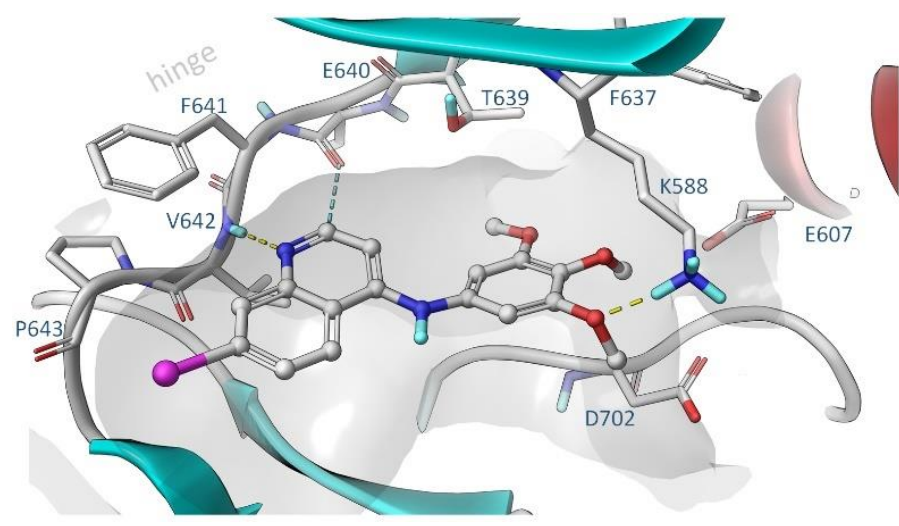<smiles>COc1cc(Nc2ccnc3cc(I)ccc23)cc(OC)c1OC</smiles>

We developed several small focused libraries of 4 -anilinoquinolines to investigate a screening hit on a understudied kinase Protein Kinase Novel 3 (PKN3). This to the identification of 7-iodo- $N$-(3,4,5-trimethoxyphenyl)quinolin-4-amine 16 as a potent inhibitor of PKN3 with an $\mathrm{IC}_{50}$ of $1.3 \mu \mathrm{M}$ in cells. Compound 16 is a potentially useful tool to study PKN3 biology including links to pancreatic and prostate cancer, along with T-cell acute lymphoblastic leukemia. These compounds may be useful tools to explore the therapeutic potential of PKN3 inhibition in prevention of a broad range of infectious and systemic diseases. 